Title: AMEE Consensus Statement: Planetary Health and Education for Sustainable Healthcare Short title: Planetary Health Education: A consensus

\title{
Authors:
}

Emily Shaw, Newcastle University

Sarah Walpole, Newcastle Upon Tyne Hospitals NHS Foundation Trust, Newcastle University

Michelle McLean, Faculty of Health Sciences \& Medicine, Bond University

Carmen Alvares-Nieto, Universidad de Jaén Campus de las Lagunillas, Nursing

Paraje

Stefi Barna, Centre for Sustainable Healthcare

Kate Bazin, King's College London Faculty of Life Sciences and Medicine, Department of Physiotherapy

Georgia Behrens, University of Notre Dame, Australia, School of Medicine

Hannah Chase, University of Oxford

Brett Duane, Trinity College Dublin, School of Dentistry

Omnia El Omrani, International Federation of Medical Students' Associations

Marie Elf, School of Education, Health and social studies, Department of Nursing, Dalarna University

Carlos Faerron, Planetary Health Alliance, Harvard University T H Chan School of Public Health, Department of Environmental Health

Enrique Falceto de Barros, Universidade de Caxias do Sul

TrevorJ Gibbs, AMEE

Jonny Groome, Greener Anaesthesia \& Sustainability Project, Great Ormond Street Hospital for Children

Finola Hackett, University of Calgary, CFMS Health and Environment Adaptive Response Task Force Jeni Harden, University of Edinburgh Usher Institute of Population Health Sciences and Informatics Eleanor J Hothersall, University of Dundee, Medical School

Maca Hourihane, Irish Society of Chartered Physiotherapists and Healthcare Professionals in International Health and Development, Irish Red Cross

Norma May Huss, Hochschule Esslingen, SAGP

Moses Ikiugu, University of South Dakota School of Health Sciences, Occupational Therapy

Easter Joury, Queen Mary University of London Barts and The London School of Medicine and Dentistry, Institute of Dentistry 
Kathleen Leedham-Green, Imperial College London Faculty of Medicine, Medical Education Research Unit

Kristen MacKenzie-Shalders, Bond University, Nutrition and Dietetics Research Group, Faculty of Health Sciences and Medicine

Lynne Madden, University of Notre Dame Australia, School of Medicine

Judy McKimm, Swansea University, Medical School

Patricia Nayna Schwerdtle, Heidelberg Institute of Global Health

Sarah Peters, University of Oxford,

Nicole Redvers, University of North Dakota, Family \& Community Medicine, Arctic Indigenous

Wellness Foundation

Perry Sheffield, Icahn School of Medicine at Mount Sinai, Departments of Environmental Medicine and Public Health and Pediatrics

Judith Singleton, School of Clinical Sciences (Pharmacy) | Faculty of Health Queensland University of Technology

SanYuMay Tun, Imperial College London, Centre for Environmental Policy

Robert Woollard, The University of British Columbia, Family Practice

Institutions at which research conducted: Home institutions of the authors + online collaboration

Corresponding author: Sarah C Walpole, Department of Infectious Diseases, Royal Victoria Infirmary, Queen Victoria Road, Newcastle. NE1 4LP. UK. 0044191 2336161. No fax available. 


\section{AMEE Consensus Statement: Planetary Health and Education for Sustainable Healthcare}

\section{Purpose of the Consensus Statement}

The purpose of this Consensus Statement is to provide a global, collaborative, representative and inclusive vision for educating an interprofessional healthcare workforce that can deliver sustainable healthcare and promote planetary health. It is intended to inform national and global accreditation standards, planning and action at the institutional level as well as highlight the role of individuals in transforming health professions education.

Many countries have agreed to 'rapid, far-reaching and unprecedented changes' to reduce greenhouse gas emissions by $45 \%$ within 10 years and achieve carbon neutrality by 2050 , including in healthcare (Intergovernmental Panel on Climate Change 2018). Currently, however, health professions graduates are not prepared for their roles in achieving these changes. Thus, to reduce emissions and meet the 2030 Sustainable Development Goals (SDGs) (United Nations General Assembly 2015), health professions education must equip undergraduates, and those already qualified, with the knowledge, skills, values, competence and confidence they need to sustainably promote the health and well-being of current and future generations, as well as that of the planet.

The current imperative for action on environmental issues such as climate change requires health professionals to mobilize politically as they have before, becoming strong advocates for major environmental, social and economic change. A truly ethical relationship with our fellow citizens and the planet that we inhabit so precariously, and to guarantee a future for the generations which follow, demands nothing less of all health professionals.

This Consensus Statement outlines the changes required in health professions education, approaches to achieve these changes and a timeline for action linked to the internationally agreed SDGs. It represents the collective vision of health professionals, educators and students from various health professions, geographic locations and cultures. 'Consensus' implies broad agreement amongst all individuals engaged in discussion on a specific issue, which in this instance, is agreement by all signatories of this Statement developed under the auspices of the Association for Medical Education in Europe (AMEE).

To ensure a shared understanding and to accurately convey information, we outline key terms in a glossary which accompanies this Consensus Statement (Appendix 1). We acknowledge, however, that terms evolve and that different terms resonate variably depending on factors such as setting and audience. We define education for sustainable healthcare as the process of equipping current and future health professionals with the knowledge, values, confidence and capacity to provide environmentally sustainable services through health professions education (Walpole and Mortimer 2017) We define a health professional as a person who has gained a professional qualification for work in the health system, whether in healthcare delivery, public health or a managementor supporting role and education as 'the system comprising structures, curricula, faculty and activities contributing to a learning process'. This Statement is relevant to the full continuum of training from undergraduate to postgraduate and continuing professional development.

\section{Introduction}

For millions of years, the Earth has sustained a diversity of life on land and sea. Since the industrial revolution, human development has harnessed the power of fossil fuels and other natural resources and rapidly reshaped environments to meet our needs. The scale of urbanization, industrial 
agriculture and anthropogenic carbon emissions has, however, led to a range of global environmental changes, including deforestation, biodiversity loss, ocean acidification and air, water and soil pollution and climate change (Frumkin and Haines 2019; Barna et al. 2020) - collectively referred to in this Statement as ecological crisis.

Industrialization was generally enabled by Western nations exploiting the Global South, in the form of colonization, mass enslavement and even genocide (Lewis and Maslin 2015). Present-day ecological crises that undermine the health of people across the globe are rooted in the practices of colonialism and capitalism, in particular the $16^{\text {th }}$ century colonization of the Americas, where the trans-Atlantic enslavement of people and the homogenization of ag riculture gave birth to plantation economies and global trade (Sealey-Huggins 2017). Over the past four centuries, the beliefs justifying the superiority of some humans over others also justified the exploitation of the planet's natural systems. This violence lies at the foundations of contemporary global society and at the root of health inequality. As such, the global ecological crisis we face has its roots in, and perpetuates, deep ecological and social injustice. Furthermore, the ecological crisis will disproportionately impact vulnerable groups such as those in the Global South, Indigenous Peoples and people of color (Thomas et al. 2019). Thus, the ecological crisis is deeply intertwined with issues of inequity and human rights.

Humanity now faces an ecological crisis that threatens the ecosystems on which we rely. The human population is expected to increase to 8.6 billion people by 2030 and nearly 10 billion by 2050 (United Nations 2017), with concomitant social and economic development increasing de mand on natural resources. We have been "mortgaging the health of future generations" (Whitmee et al. 2015; p.1973), expending resources at a far greater rate than they can be replenished in nature, bringing us to a present which has been termed the Anthropocene (Lewis and Maslin 2015; Weidmann et al. 2020).

To limit global warming to $1.5^{\circ} \mathrm{C}$, as per the Paris Agreement (United Nations 2015), greenhouse gas emissions must be reduced by $45 \%$ (from 2010 levels) by 2030 and to net zero by 2050 (IPCC 2018). A $0.5^{\circ} \mathrm{C}$ of warming (i.e. from $1.5^{\circ} \mathrm{C}$ to $2.0^{\circ} \mathrm{C}$ ) is expected to result in increased risks to health, food security, water supply, human security and livelihoods. Climate change can increase the frequency of flooding, heat waves and natural disasters, all of which cause injury and disease and may directly impact healthcare facilities. For Höhne and colleagues (2020), a wasted decade has shortened the timeframe to act: "In 2010, the world thought that it had 30 years to halve globalemissions of greenhouse gases. Today, we know that this must happen in ten years to minimize the effects of climate change" (p. 25).

Health systems are responsible for about $4.4 \%$ of the world's greenhouse gas emissions ( Health Care Without Harm 2019). Healthcare is also responsible for a broader environmental impact of between $1 \%$ and $5 \%$ of the total global impact and more than $5 \%$ for some national impacts (Lenzen et al. 2020). Healthcare thus contributes to ill-health through emissions, which cause climate change and other environmental impacts including air pollution (e.g. through waste incineration) and water pollution (e.g. through pharmaceutical waste) (Eckleman and Sherman 2018; Health Without Harm 2019; Lenzen et al. 2020). The health professions therefore have a moral obligation to take action to reduce the environmental impacts of healthcare provision. As well as working to mitigate further environmental degradation, health professionals will need to develop climate resilient healthcare facilities (WHO 2020) - equipped to anticipate, respond to and adapt to climate impacts already underway such as altered patterns of disease, threats to infrastructure due to changing weather patterns and psychological impacts. These will require ambitious and clear plans, with flexibility to monitor progress and adapt as circumstances change. 


\section{Planetary health solutions}

There are many cultural models for living in harmony with the Earth, whilst also meeting humanity's needs. Indigenous People across the world have long acted as custodians of the environment, recognizing the interconnectedness of all living things, including the impact of all elements of the planet on well-being, health and spirituality. Western medical practice, often focused on the biomedical model, has neglected this traditional Indigenous wisdom, wisdom which can enhance our ability to promote planetary health and ability to deliver education for sustainable healthcare. Planetary health pertains to the interdependent vitality of human and earth systems, both biological and socially constructed. Education for sustainable healthcare necessarily incorporates planetary health principles. Indigenous populations have long held conceptions of planetary health (Indigenous traditional knowledge) and the interconnectedness of all beings on the planet (Redvers et al. 2020). Planetary health is inclusive of all species and environments and emphasizes equally 'all that is known about the world around us and how to apply that knowledge in relation to those beings that share the world' (Bennett et al. 2014, p. 301)

Whilst each country has a unique context with regard to Indigenous Peoples and colonialist history, an increased focus on the interdependence of all life on Earth has application to health professionals across the world. This focus ensures a health workforce that is informed about the interdependence of ecosystems and health, prepared to tackle social and ecological injustice and inequities and possesses the skills, values and capabilities to respond.

Recognizing that development must protect and promote human rights and be equitable and environmentally sustainable, the United Nation's 2030 Sustainable Development Goals (SDGs) provide a framework for action at all levels - global, national, institutional and individual. As the 'Accelerating Education for the SDGs' Report describes, universities play a vital role in helping society to meet the 2030 target (Sustainable Development Solutions Network 2020). Universities can facilitate 'Education for the SDGs' by equipping students with the knowledge, skills and motivation necessary to tackle complex problems that we face as a society, such as the ecological crisis. They can also motivate learners to become active agents in working towards a sustainable future (Box 1$)$.

\section{INSERT BOX 1 HERE}

To ensure a sustainable existence, we must address inequalities, respect human rights and become stewards of our planet's limited resources. Raworth's (2017) 'Doughnut model' is useful for depicting the social and ecological boundaries that encompass human well-being which need to be preserved to promote 'a safe and just space for humanity' (Figure 1). This requires us to challenge existing power structures that often perpetuate overuse of resources and exacerbate inequalities. For health professionals specifically, the values enshrined in the human rights discourse have the potential to lead the way within the social foundation necessary for the health of our planet.

\section{INSERT FIGURE 1 HERE}




\section{Role of health professionals}

There is a growing recognition among health professionals that the current ecological crisis poses a major threat to human health and well-being. Many health professional bodies have responded by declaring a climate crisis or emergency (e.g. WONCA World Organization of Family Doctors, Environmental Physiotherapy Association and International Council of Nurses) and calling for environmental sustainability and re source stewardship in healthcare (e.g. the World Medical Association and the Australian Medical Association). Many health professionals and their organizations are calling for action, including developing the evidence base on the interactions between environmental change and health, reducing negative environmental and health impacts of health systems, educating professionals, educating the public, lobbying policymakers and preparing health systems to manage the direct impacts of the ecological crisis (e.g. the WHO 2020 Guidance for Climate Resilient and Environmentally Sustainable Health Care Facilities document).

Health professionals can drive social and policy change (Haines and Ebi 2019) as they are generally highly trusted (Gallup poll 2019) and have influence at all levels of society. With trust comes responsibility to influence wisely and lead effectively, which requires collaborative engagement beyond individual actions, thus "Health professionals will be called on to engage as humble, informed, and trusted partners in the collective, boundary-crossing effort of transforming practices and structures to better sustain the health and well-being of all life, including our own" (Parkes et al. 2020; p. 4).

Education has been identified as having an essential role in attaining the Sustainable Development Goals and stabilizing the Earth's climate by 2050 (Otto et al. 2020). Consequently, we must rapidly mobilize health professions educators to deliver education for sustainable healthcare. Setting targets, developing indicators, and measuring and monitoring progress can help achieve change across the sector.

This Consensus Statement explores how the health professions can and must prepare the health workforce, including healthcare leaders, to deliver on this agenda. In a recent survey of the inclusion of climate change and air pollution in the medical curricula in more than 100 countries, only $15 \%$ of medical schools had included climate change and even fewer had incorporated air pollution (El Omrani et al. 2020). These omissions further highlight the urgency as education is considered one of the important tipping points for action (Otto et al 2020; McLean et al. 2020).

\section{Vision for education for sustainable healthcare}

The "responsibility for planetary health requires us to relinquish conventional professional, societal, and cultural partitions and to develop contextual coalitions based both on science and broader cultural narratives" (Prescott and Logan 2018; p. 3).

The overarching education for sustainable healthcare vision is one in which positive changes to education, healthcare, public health and planetary health are achieved through collective, collaborative, non-hierarchical and inclusive commitment and action. Our vision for education for sustainable healthcare emphasizes ecological accountability through environmental stewardship (care-taking) of the living planet - by health professionals and health and education institutions. It 
respects Indigenous knowledge in terms of the link between people and the planet. Education for sustainable healthcare needs to ensure a health workforce that is informed about the interdependence of the ecosystems and health, possesses the skills, values and capabilities to drive change and is mobilized and motivated to foster change.

In this Consensus Statement, we affirm the duty of all health professionals to protect and promote health of both the planet and all of its inhabitants in the context of humanity's complete dependence on the ecosystems within which we live (Prescott et al. 2018). We support learning that equips health professionals to meet th is duty. We acknowledge that Indigenous People across the world have long acted as custodians of the environment, recognizing the interconnectedness of all living things, including the impact of all elements of the planet on spirituality, well-being and health. In line with this approach, health professions educators need to highlight the complex challenges related to the ecological crisis and how human lives and well-being are directly dependent upon the natural world.

Education for sustainable healthcare practices are synergistic with promoting planetary health (Prescott et al. 2018). Shared, evidence-informed practices can advance health and environmental sustainability, reduce health inequalities, minimize the environmental footprint of health systems and strengthen populations' resilience to environmental change, thereby contributing to overall wellness for our communities while ensuring the continued existence of all living organisms. For practitioners to be cognizant of and responsive to planetary health requires not only relevant knowledge and skills, but also values. Education for sustainable healthcare engenders these values, such as prioritization of health equity, human rights and respect for life and ecosystems. Figure 2 depicts the vision for education for sustainable healthcare where knowledge and values inform practices, informed by Indigenous perspectives and part of a wider planetary health paradigm.

INSERT FIGURE 2 here

This vision and Consensus Statement are guided by Indigenous traditional wisdom and connection to nature, informed by evidence on the safe operating space for humanity and Raworth's do ughnut (Figure 1) and shaped to align with the internationally agreed SDGs (Box 1). This developing education for sustainable healthcare vision is part of a growing positive response to the ecological crisis that we are currently experiencing. It outlines some important directions for healthcare institutions. We have an increasing need for professionals, citizens and leaders - healers, if you will - who are able to adapt and move quickly to educate both existing and emerging practitioners to address our collective future and the well-being of our shared home.

\section{Enacting the vision}

Our vision for education for sustainable healthcare demands a shift from rhetoric to action. Action requires understanding, acceptance and strategies for leading a major culture change - from the glorification of consumption and economic growth to working towards health and sustainability for all. Education for sustainable healthcare leaders require understanding of organizational behavior and politics in the real world. Education for sustainable healthcare encompasses environmental accountability as defined by Pearson et al. (2015), the obligation to ensure that education and research contribute to active development, promotion and protection of environmentally and 
ecologically sustainable solutions (Boelen et al. 2016). It also aligns with social accountability, the responsibility of health education institutions to focus their considerable resources and capacity on the priority health concerns of the societies which they serve (Woollard 2006; Woollard and Boelen 2012; Boelen et al. 2016).

Health professions educators must aspire to facilitate learning in a very different way and to incorporate environmental and ecological sustainability into curricula (Walpole et al.

2017). Educators must also nurture transdisciplinary problem-solving to bring disciplines together to design curricula to promote the best possible outcomes for patients, communities and the planet (Schwerdtle et al. 2020). Nurturing knowledge, skill development and values can move learners and educators beyond despair to engagement (Walpole et al. 2015). Today's health professionals must be equipped to respond to local and global environmental changes as urgent threats and address wide-ranging health, healthcare and sustainability challenges (Sterling 2015; UNESCO 2014a). In such an emergency, eco-ethical leadership is required (McKimm and McLean 2020; McKimm et al. 2020).

\section{Leadership in a complex world}

Health professionals work in multiple, overlapping, dynamic biological, social and ecological VUCA (Volatile, Uncertain, Complex and Ambiguous) systems (Mack et al. 2015), within a nested hierarchy of domains, ranging from the personal to the family, community and national and international levels. In many Indigenous communities, the responsibility to act as stewards for the planet is central (Greenleaf 2008) to pass it on in the best shape to generations who follow (McKimm and O'Sullivan 2016). This responsibility is not new but the current ecological crisis makes it urgent.

To achieve the education for sustainable healthcare vision, an 'eco-ethical' leadership approach, integrated around environmental and ecological sustainability, values, collaboration, justice, advocacy and activism, designed to address issues in complex systems must be applied by health professions educators and incorporated in learning (McKimm and McLean 2020). Eco-ethical leadership facilitates meaningful and sustainable change throug h understanding of how people and systems work and interact to create change. Addressing sustainability issues can cause strong or overwhelming reactions in staff or students, which need to be recognized and directed to appropriate sources of support (Tun 2019). Eco-ethical leadership enables translation of policy and strategy into meaningful action and working with paradox, uncertainty and ambiguity whilst retaining moral purpose (Obolensky 2017).

Eco-ethical leadership must embrace an inclusive approach that welcomes diverse cultural views. From an Indigenous perspective, education for sustainable healthcare can be seen as being rooted in the land as a medicine place, i.e. a place that brings healing and greater overall well-being (Redvers 2018). Health professions education informed by Indigenous knowledge systems recognizes the interconnectivity of all life on the planet. This calls for inclusive leadership skills which cross existing boundaries and domains to foster innovation, effective engagement practices and inclusiveness, while utilizing the strengths of collective intelligence (Kuenkel 2016).

\section{Engaging faculty}

To enact this vision, faculty engagement is essential. Faculty must recognize that addressing environmental and ecological issues is a matter of utmost urgency and should be a core priority for the health service as well as the duty of all health professionals. Sustainability literacy is essential if faculty are to educate for sustainable healthcare, yet environmental concepts may not be familiar to 
all health professions educators. Faculty development can help prepare and support faculty in assuming their new roles as sustainability educators. Key concepts in sustainability include causes of the ecological crisis, the health impacts and the ethical dimensions, sustainable healthcare delivery and clinical practice (Tun et al. 2020).

As health professional students may already be familiar with environmental issues, through knowledge acquired in their secondary school curriculum or the school Climate Change Strikes. Thus, they are ideally placed to partner with academics not only by helping to integrate sustainability concepts into curricula but also by contributing to faculty development. To this end, student organizations have created resources that can be used for curriculum planning and faculty development, such as the International Federation of Medical Students' Associations' climate change short course and the Canadian Federation of Medical Students' planetary health competencies. In addition, Tun and colleagues' (2020) recent Medical Teacher Special Issue article provides case studies of student contributions to faculty development in planetary health and sustainable healthcare.

Institutional support is also essential. This can include offering continuing professional development and awards for innovation to incentivize progress. Those who develop best practice activities can be involved in training others. Institutions need to 'walk the sustainability talk' and, where possible, promote practices such as virtual and distance learning to reduce the environmental footprint of travel.

Developing a curriculum that incorporates planetary health and sustainable healthcare on campus, in the community and in healthcare settings can enhance faculty satisfaction and self-efficacy (Tun et al. 2020; Brand et al. 2020). Faculty development fosters in-depth learning and a sense of meaningful interaction with others, both of which may improve personal and professional well-being in the face of our climate emergency.

Next, the Consensus Statement explores how health professions education can be adapted to address the urgency of the ecological crisis we are currently facing. It outlines key knowledge, skills and values that health professionals will need to be able practice sustainable healthcare and suggests pedagogies and assessment strategies. We acknowledge, however, that the knowledge, skills and values required to practice sustainable healthcare will vary across the world and by profession.

\section{Sustainability literacy, skills and values}

Drawing on the education for sustainable healthcare vision, this section describes what health professionals need to learn, be able to do and what values they should espouse. While we need to collaborate across health disciplines in line with clinical practice (Schwerdtle et al. 2020), we acknowledge that one size does not fit all and each institution needs to tailor the integration depending on its local needs - 'think globally, act locally'. The learning outcomes in Table 1 have been adapted from the Centre for Sustainable Healthcare to include skills and values. Higher order activities, such as 'apply' and 'evaluate' are essential to ensure learners are prepared to make a difference in the real world (Adams 2015). While it is important for health professionals to acquire and apply knowledge and learn skills and appropriate professional behaviors, it is equally important that educators consider the role of values and emotions. Values-based education helps prepare health professionals to work towards the SDGs. The affective (emotion-based) components of learning and responses to learning (including eco-anxiety) must be supported (Burford et al. 2016; Huss et al. 2020). As the field is constantly evolving, professionals need to actively engage in 
continuing professional development to ensure life-long learning (Field 2010). Equity and human rights must be central to this framework. There must be an awareness of how the ecological crisis disproportionately affects certain populations, including Indigenous groups, communities of color, the elderly and the young, rural communities, people living with long-term conditions and disabilities and on low incomes.

Below, we offer suggestions and examples of curriculum planning and delivery of education interventions that can be adapted for local contexts. Sustainability should be integrated across all years of the curriculum rather than being a series of stand-alone or add-on elements. A first step to integration is to identify core education for sustainable healthcare learning outcomes and map these to local curricula, professional competencies or other relevant frameworks (NurSus Interim Report 2015; Lopez-Medina et al. 2019, Tun 2019; Table 1). Introducing practical learning experiences in sustainable healthcare early in training emphasizes these concepts and principles as core components of professional identity (Prescott et al. 2018). Given the complexity of the ecological crisis, a transdisciplinary approach to learning is essential (Schwerdtle et al. 2020). This transdisciplinary focus bridges traditional divides between disciplines to ensure collective vision, problem-solving and action.

\section{INSERT TABLE 1 HERE}

We thus advocate experiential, transdisciplinary learning that engages individuals in activities that require critical thinking, communication, leadership and change management (Table 2). At its best, education for sustainable healthcare will draw on personal experiences, stimulate discovery, encourage problem-solving and be relevant to learners' future health professional roles. Learning activities assist with progressing from understanding how the ecological crisis impacts health to creatively addressing problems, including local and global interventions that not only involve adaptation and development of resilience, but also reduce the environmental impact of healthcare through resource stewardship and education of patients on topics such as the co-benefits of exercise and plant-based diets.

\section{Assessment}

Assessment can motivate students to learn (Miller 1990). Thus, to ensure that health professionals gain the essential knowledge and develop the appropriate skills and values to advance sustainable healthcare, assessment must not only be constructively aligned with education for sustainable healthcare learning outcomes, but must be authentic (Gulikers et al. 2004), acceptable, fair and costeffective (Norcini et al. 2018).

Assessment must test competence in understanding and applying broad and complex planetary health concepts at a global and a local level. Competence in the cognitive (i.e. knowledge) and psychomotor (i.e. manual skills) domains can generally be 'measured' using standardized assessment instruments such as multiple-choice questions or Objective Structure d Clinical Examinations (OSCEs). Assessment of the complex concepts and the affective domain is more difficult to assess and is generally considered more subjective (Smith et al. 2007). As the global community increasingly faces complex problems that impact on our health and well-being, e.g. ecosystem disruption, climate change, pollution and pandemics such as COVID-19, assessment of competency needs to 
accommodate creative solutions to these complex problems and differences in values or perspectives.

Thus, to educate fit-for-practice health professionals, assessment not only tests acquisition of knowledge but also its application. Learning is not only about knowing but also about ways of 'being'. If the aim of assessment is to drive the appropriate learning, then reliability is only critical in 'high stakes' scenarios where there are progression implications. Assessment can be more developmental than judgmental (i.e. for, rather than of, learning). To develop skills and values to mitigate and address planetary health challenges, we need more authentic approaches that allow multiple views of a learner's progress and also provide opportunities for individual creativity (Feltovich et al. 1993) while fostering the appropriate values (e.g. empathy and advocacy) and behavior (e.g. activism). Finally, assessment communicates what is valued by a profession (Boud 2000).

Professional bodies should include assessment of education for sustainable healthcare learning outcomes. Table 2 provides a range of assessment approaches with suggestions for ensuring students achieve the required competencies in education for sustainable healthcare.

\section{INSERT TABLE 2 HERE}

\section{Practical recommendations for implementing and evaluating education for sustainable healthcare}

This section presents specific recommendations to enact the education for sustainable healthcare vision, including indicators to monitor progress and a road map for implementation, including specific, time-bound recommendations. Further resources to support implementation are available in Appendix 2.

\section{Proposed indicators for education for sustainable healthcare}

Few targets and indicators for the inclusion of education for sustainable healthcare exist (Madden et al. 2020). Three SDGs include a target and a linked indicator relevant to education for sustainability (Box 1). An international medical student initiative has recently produced a set of indicators to assess the progress of medical schools in incorporating planetary health (https://phreportcard.org/our-metrics/). Other examples of indicators address only one aspect (e.g. climate change) of many environmental changes that impact health and well-being. For example, in Australia, the MJA Lancet Countdown recently added a new indicator to monitor The inclusion of health and climate change in medical curricula (Beggs et al. 2019). Annual reporting will commence in 2021.

How can targets and indicators help? By measuring and monitoring what we do, we can identify whether strategies and interventions to create change are effective. Well-constructed indicators also provide a tool for communication about progress and can inform change. Indicators, where they exist, can also inform us whether institutions are meeting accreditation requirements for education for sustainable healthcare. Targets and indicators are best refined in consultation with the community of practice (Navi et al. 2017). There is thus a need for engagement of the health professional community to use existing indicators and develop robust indicators to measure and monitor progress.

Proposed targets for education for sustainable healthcare 
Table 3 provides recommendations for educators, health education institutions, health professions regulators and health professional organisations. For example, accreditation standards for the regulated health professions should reflect the environment and climate change as a determinant of health and the responsibility of health professionals to practice environmentally sustainable healthcare. Health professional organizations, from trade unions to international organizations such as AMEE, can play a role. Their scope, skills and mandate vary greatly and some or all of the recommendations may be applicable. When organizations develop and enact a plan to reduce the environmental impacts of healthcare, this models good practice and can be an aspect of eco-ethical leadership. 'Eco-ethical' leadership also involves embracing and welcoming diverse cultural views, advocacy and role modelling (McKimm and McLean 2020).

\section{INSERT TABLE 3 HERE}

\section{Concluding comments}

Over the year-long development of this Consensus Statement, there has been wide and inclusive consultation across health professions, representing many countries, and reflecting the insights of Indigenous Peoples whose traditional knowledge and voices have largely been marginalized. This Consensus Statement reflects the current situation and is by no means exhaustive. Its primary purpose is to create an awareness of the important role of health professions educators and health professional institutions in advancing environmental accountability and to offer some direction for those who are new to this space. While this Consensus Statement focuses on education for sustainable healthcare, the broader lens of planetary health is particularly relevant to health professionals, to ensure an inclusive, respectful, collaborative, transdisciplinary response to address the ecological crisis currently impacting on our health and well-being as well as that of our planet.

Our health and well-being are dependent on a healthy planet. The window of opportunity to protect our ecosystems is fast disappearing, so urgent, collective, transdisciplinary action is required. The 2020s could be a decade in which we step up action on pressing issues such as a changing climate. While COVID-19stopped us in our tracks, it has also been a wake-up call. Our relationship with nature is broken and with an increasing but unequal affluence over the past 50 years and our unsustainable impact on the planet's ecosystems, not only our health but also survival is at stake. Given the dependence of human health on ecosystems, there is a need for eco-ethical leaders who can inspire current and future generations of healthcare professionals to become environmental stewards who strive towards a safe and just space for humanity and all of Earth's inhabitants.

\section{Practice points}

- Health professionals must be prepared to deliver system-wide changes to mitigate and adapt to the ecological crisis.

- Education for sustainable healthcare (ESH) includes mainstreaming planetary health as a transversal curricular theme. 
- Faculty development, eco-ethical leadership and transdisciplinary and interdisciplinary planetary health action are urgently needed.

- ESH guidance plus ESH learning and assessment resources are already available

- ESH accreditation standards, indicators and progress monitoring are required. 


\section{Acknowledgements:}

We would like to thank Teddie Potter, Arianne Teherani and Caroline Wellbery who have kindly shared their expertise and their time as expert reviewers.

Declaration of interests: Trevor Gibbs is President of AMEE. All other authors have no conflicts of interest to declare.

Keywords: Assessment, Curriculum, Staff development (management), Health promotion (Learning outcomes), Leadership (Learning outcomes)

\section{References}

Adams N. 2015. Bloom's taxonomy of cognitive learning objectives. Journal of the Medical Library Association. 103(3): 152-153

Barna S, Maric F, Simons J, Kumar S, Blankenstijn PJ. 2020. Education for the Anthropocene: Planetary health, sustainable health care, and the health workforce. Med. Teach. 42(10):1091-1096.

Beggs PJ, Zhag Y, Babrick H et al. 2019. The 2019 report of the MJA-Lancet Countdown on health and climate change: a turbulent year with mixed progress. MJA. 211(11):490-491. https://www.mja.com.au/journal/2019/211/11/2019-report-mja-lancet-countdown-health-andclimate-change-turbulent-year-mixed.

Bennett TCB, Maynard N, Cochran P, Gough R, Lynn K, Maldonado J, Voggesser G, Wotkyns S, Cozzetto K. 2014. Chapter 12. Indigenous peoples, lands, and resources. In: Melillo JM, Richmond TC, Yohe GW, editors. Climate change impacts in the United States: the third national climate assessment. Washington (DC): U.S. Global Change Research Program; p. 297-317.

Boelen C, Pearson D, Kaufman A, Rourke J, Woollard R, Marsh DC, Gibbs. T. 2016. Producing a socially accountable medical school: AMEE Guide No. 109. Med Teach. 38(11):1078-1091.

Boud D. 2000. Sustainable assessment: rethinking assessment for the learning society. Studies in Continuing Education 22(2):151-167

Brand G, Collins J, Bedi G, Bonnamy J, Barbour L, Ilangakoon C, Wotherspoon R, Simmons, KM, Nayna Schwerdtle P. 2020. I teach it because it is the biggest threat to health: Integrating a Planetary Health perspective into health professions education. Medical Teacher. Med Teach. Accepted for publication.

Burford G, Tamás P, Harder MK. 2016. Can we improve indicator design for complex sustainable development goals? A comparison of a values-based and conventional approach. Sustainability. 8(9):861. https://www.mdpi.com/2071-1050/8/9/86.

Eckelman MJ, Sherman JD. 2018 Estimated global disease burden from US health vare sector greenhouse gas emissions. Am J Pub Health. 108:S120-

S122. https://doi.org/10.2105/AJPH.2017.303846 
El Omrani O, Dafallah A, Castillo BP, Amara BQRC, Taneja S, Amzil M, Sajic MRU, Ezzine T. 2020. Envisioning planetary health in every medical curriculum: An international medical student organization's perspective. Med Teach. 42(10):1107-1111.

Feltovich PJ, Spiro RJ, Coulson RL. 1993. Learning, Teaching, and Testing for Complex Conceptual Understanding. In: Frederiksen N, Mislevy RJ, Bejar IK, editors. Test Theory for a New Generation of Tests. Hillsdale (NJ): Lawrence Erlbaum Associates; p. 181-217.

Field J. 2010. Lifelong learning. In: Rubenson, K. Adult Learning and Education (pp. 20-26) Oxford, UK. Elsevier Ltd.

Frumkin H, Haines A. 2019. Global environmental change and noncommunicable disease risks. Ann Rev Pub Health. 40 :261-282. https://www.annualreviews.org/doi/abs/10.1146/annurev-publhealth040218-043706.

Greenleaf, R.K., 2008. Who is the servant-leader?. The International Journal of ServantLeadership. 4(1):29-37.

Gulikers J, Bastiaens T, KirschnerP. 2004. A five-dimensional framework for authentic assessment. Educ Tech Res Devel. 52(3):67-85.

Haines A, Ebi K. 2019. The imperative for climate action to protect health. New Engl J Med. 280:263273. https://www.nejm.org/doi/pdf/10.1056/NEJMra1807873

Health Care Without Harm. 2019. Health care climate footprint report. https://noharmuscanada.org/ClimateFootprintReport

Höhne N, deb Elzen M, Rogelj J et al. Emissions: world has four times the work or one-third of the time. Nature. 57:25-28. https://media.nature.com/original/magazine-assets/d41586-020-00571x/d41586-020-00571-x.pdf

Huss N, Ikiugu MN, Hackett F, Sheffield PE, Palipane N, Groome J. 2020. Education for sustainable health care: From learning to professional practice. Med Teach. 41(10):1097-1101.

International Panel on Climate Change (IPCC). 2018. Summary for policymakers. https://www.ipcc.ch/site/assets/uploads/sites/2/2019/05/SR15_SPM_version_report_LR.pdf. https://www.ipcc.ch/sr15/

Kuenkel P. 2016. The art of leading collectively: Co-creating a sustainable, socially just future. Place: Chelsea Green Publishing.

Lewis S, Maslin M. 2015. Defining the Anthropocene. Nature. 519(7542):171-80Lenzen M, Malik A, Li M, Fry J, Weisz H, Pichler PP. 2020. Environmental footprint of healthcare: a global assessment. Lancet Planetary Health. 4(7):e271-e279.

https://www.thelancet.com/journals/lanplh/article/PIIS2542-5196(20)30121-2/fulltext

Lopez-Medina I.M, Álvarez-Nieto C, Grose J, Elsbernd A, Huss N, Huynen M, Richardson J. 2019. Competencies on environmental health and pedagogical approaches in the nursing curriculum: $A$ systematic review of the literature. Nurse Education in Practice 37 1-8

https://doi.org/10.1016/j.nepr.2019.04.004

Mack O, Khare A, KrämerA, Burgartz, T. eds. 2015. Managing in a VUCA World. Place: Springer. 
Madden DL, McLean M, Brennan M, Moore A. 2020. Why use indicators to measure and monitor the inclusion of climate change and environmental sustainability in health professions' education. Med Teach. 42(10):1119-1122.

McKimm J, McLean M. 2020. Rethinking health professions' education leadership: Developing 'ecoethical' leaders for a more sustainable world and future. Med Teach. 42(8):1-6.

McKimm J, O’Sullivan H. 2016. When I say...leadership. Med Educ. 50(9):896-897.

McKimm J, Redvers N, El Omrani O, Parkes MW, Elf M, Woollard R. 2020. Education for sustainable healthcare: Leadership to get from here to there. Med Teach. 42(10):1123-1127.

McLean M, Gibbs TJ, McKimm J. 2020. Educating for planetary health and environmentally sustainable health care: Responding with urgency. Med Teach. 42(10):1082-1084

Miller GE. 1990. The assessment of clinical skills/competence/performance. Acad Med. 65(9): S63S67.

Mortimer F, Isherwood J, Wilkinson A, Vaux E. 2018. Sustainability in quality improvement: redefining value. Future Healthc J. 5(2):88-93.

Navi M, Hansen A, Bitschke M, Hanson-Easy S, Pisaniello A. 2017. Developing health-related indicators of climate change: Australian stakeholder perspectives. Int J Environ Res Public Health14: 552. https://www.mdpi.com/1660-4601/14/5/552.

NurSus. 2015. Interim Report August 2015: A Delphi study and thematic analyses of curricula to identify opportunities for embedding sustainability in nursing curricula. [Accessed 2020 October 22]. http://nursus.eu/interim-report-august-2015-a-delphi-study-and-thematic-analyses-of-curricula-toidentify-opportunities-for-embedding-sustainability-in-nursing-curricula/

Norcini J, Brownell Anderson M, Bollela V, Burch V, Costa JM, Duvivier R, Hays R, Palacios Mackay MF, Roberts T, Swanson D. 2018. Consensus framework for good assessment: Consensus statement and recommendations from the Ottawa 2010 Conference. Med Teach. 40(11):1102-1109.

Obolensky N. 2017. Complex adaptive leadership: Embracing paradox and uncertainty. London: Routledge.

Otto IM, Donges JF, Cremades R et al. 2020. Social tipping dynamics for stabilizing the Earth's climate by 2020 . PNAS. 117(5):2354-2364.

Parkes MW, Poland B, Allison S., et al. 2020. Preparing for the future of public health: The ecological determinants of health and the call for an eco-social approach to public health education. Can J Pub Health. 111(1):60-64. https://doi.org/10.17269/s41997-019-00263-8

Pearson D, Walpole S, Barna S. 2015. Challenges to professionalism: Social accountability and global environmental change. Medical Teacher. 2015;37(9):825-830.

Prescott S, Logan A, Albrecht G, et al. 2018. The Canmore Declaration: Statement of Principles for Planetary Health. Challenges 9(2):31. https://www.mdpi.com/2078-1547/9/2/31

Prescott S, Logan A. 2019. Planetary Health: From the wellspring of holistic medicine to personal and public health imperative. Explore.15(2):98-106.

Redvers N, Schultz C, Prince MV, Cunningham M, Jones R, Blondin B. 2020. Indigenous perspectives on education for sustainable healthcare. Med Teach. 42(10):1085-1090. 
Redvers N. 2018. The value of global Indigenous knowledge in planetary health. Challenges. 9(2):30. https://www.mdpi.com/2078-1547/9/2/30

Raworth K. 2017. A Doughnut for the Anthropocene: humanity's compass in the 21st century. Lancet Planetary Health. 1:e48-e49.

Schwerdtle N, Horton G, KentF, Walker F, McLean M. 2020. Education for sustainable healthcare: A transdisciplinary approach to transversal environmental threats. Med Teach. 42(10):1102-1106.

Sealey-Huggins L. 2017. ' $1.5^{\circ} \mathrm{C}$ to stay alive': climate change, imperialism and justice for the Caribbean, Third World Quart. 38(11):2444-2463.

https://www.tandfonline.com/doi/full/10.1080/01436597.2017.1368013

Smith SR, Goldman RE, Dollase RH, Taylor JS. 2007. Assessing medical students for non-traditional competencies. Med Teach. 29(7):711-716. DOI: 10.1080/01421590701316555

Sterling S. 2015. Commentary on 'Goal 4: Education'”. In ICSU, ISSC (2015): Review of the Sustainable Development Goals: The science perspective, Paris: International Council for Science (ICSU).

Sustainable Development Solutions Network (SDSN). 2020. Accelerating Education for the SDGs in Universities: A guide for universities, colleges, and tertiary and higher education institutions. New York: SDSN.

Thomas K, Hardy RD, Lazrus H, Mendez M, Orlove B, Rivera-Collazo I, Roberts JT, Rockman M, Warner BP, Winthrop R. 2019. Explaining differential vulnerability to climate change: A social science review. WIREs Climate Change. 10(2):e565. https://doi.org/10.1002/wcc.565.

Thompson T, Walpole S, Braithwaite I, Inman A, Barna S, MortimerF. 2014. Learning objectives for sustainable health care. Lancet. 384: 1924-1925.

Tun SM. 2019. Fulfilling a new obligation: Teaching and learning of sustainable healthcare in the medical education curriculum, Med Teach., 41(10):1168-1177.

Tun S, Wellbery C, Teharani A. 2020. Faculty development and partnership with students to integrate sustainable healthcare into health professions education. Med Teach. 42(10):1112-1118.

United Nations Educational, Scientific and Cultural Organization (UNESCO). 2014a. Roadmap for Implementing the Global Action Programme on Education for Sustainable Development.

https://sustainabledevelopment.un.org/index.php?page=view\&type=400\&nr=1674\&menu=1515

United Nations Educational, Scientific and Cultural Organization (UNESCO). 2014b. Shaping the Future We Want - UN Decade of Education for Sustainable Development (2005-2014) Final Report, Paris: UNESCO. [accessed 26 April 2020].

United Nations (UN). 2017. News. [accessed https: 21 Nov 20]

//www.un.org/development/desa/en/news/population/world-population-prospects-2017.html

United Nations Framework Convention on Climate Change. 2015. Adoption of the Paris Agreement, 21st Conference of the Parties, Paris: United Nations. Paris Agreement (Dec. 13, 2015), in UNFCCC, COP Report No. 21, Addenum, at 21, U.N. Doc. FCCC/CP/2015/10/Add, 1 (Jan. 29, 2016) [hereinafter Paris Agreement].

United Nations (UN). 2020. Global indicator framework for the Sustainable Development Goals and targets of the 2030 Agenda for Sustainable Development. Global indicator framework adopted by 
the General Assembly (A/RES/71/313), annual refinements contained in E/CN.3/2018/2 (Annex II), E/CN.3/2019/2 (Annex II), and 2020 Comprehensive Review changes (AnnexII) and annual refinements (Annex III) contained in E/CN.3/2020/2.

https://unstats.un.org/sdgs/indicators/Global\%20Indicator\%20Framework\%20after\%202020\%20rev iew_Eng.pdf.

United Nations General Assembly, Transforming our world: the 2030 Agenda for Sustainable Development, 21 October 2015, A/RES/70/1, available at:

https://www.refworld.org/docid/57b6e3e44.html [accessed 16 October 2020] and also at https://www.un.org/ga/search/view_doc.asp?symbol=A/RES/70/1\&Lang=E

Walpole SC, Pearson D, Coad J, Barna S. 2015 What do tomorrow's doctors need to learn about ecosystems?-A BEME Systematic Review: BEME Guide No. 36. Vol. 10, Medical Teacher.

Walpole SC, Mortimer F. 2017. Evaluation of a collaborative project to develop sustainable healthcare education in eight UK medical schools. Public Health. 150:134-148

Walpole SC, Vyas A, Maxwell J, Canny BJ, Woollard R, Wellbery C, Leedham-Green KE, Musaeus P, Tufail-Hanif U, Pavão Patrício K, Rother H-A. 2017. Building an environmentally accountable medical curriculum through international collaboration. Med Teach 3; 39(10): 1040-50.

Weidmann T, Lenzen M, Keyßer LT, Steinberger JK. 2020. Scientists' warning on affluence. Nature Comm. 11:3107. https://www.nature.com/articles/s41467-020-16941-y

Whitmee S, Haines A, Beyrer C, Boltz F, Capon AG, de Souza Dias BF, Ezeh A, Frumkin H, Gong P, Head P. 2015. Safeguarding human health in the Anthropocene epoch: Report of The Rockefeller Foundation-Lancet Commission on planetary health. Lancet 386: 1973-2028

Woollard B, Boelen C. 2012. Seeking impact of medical schools on health: meeting the challenges of social accountability. Med Edu. 46(1):21-27.

Woollard RF. 2006. Caring for a common future: medical schools' social accountability. Med Educ. 40:301-313.

World Health Organization. 2020. WHO guidance for climate resilient and environmentally sustainable health care facilities. https://www.who.int/publications/i/item/climate-resilient-andenvironmentally-sustainable-health-care-facilities. 
Figure 1

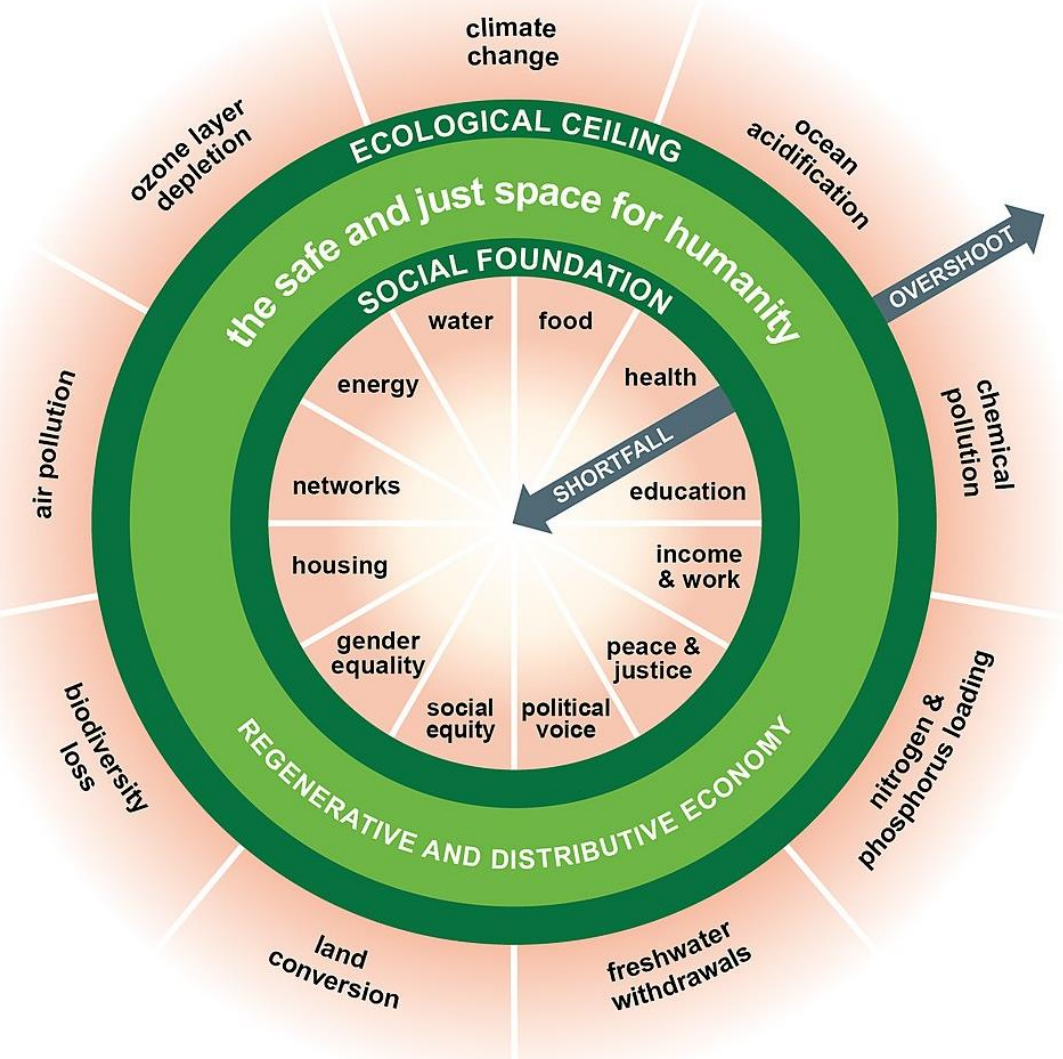

Figure 1. Raworth's (2017) Doughnut model of a regenerative and distributive economy within social and planetary boundaries (with permission)

Can be reproduced in colour and in black and white 
Figure 2

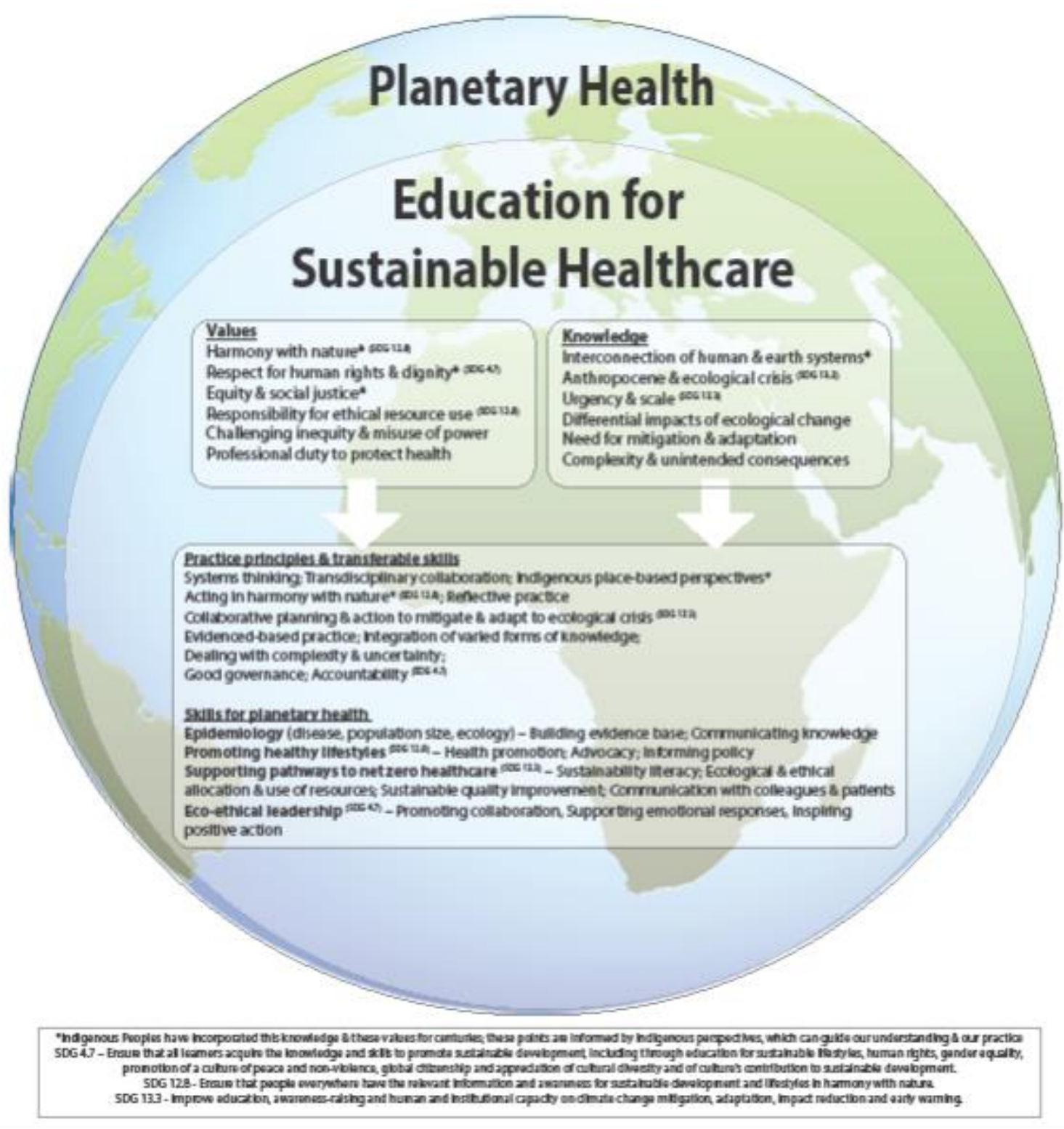


Table 1. Learning outcomes and objectives for environmentally sustainable healthcare and associated domains of learning, adap ted from the Centre for Sustainable Healthcare (Thompson et al. 2014) and the 2020 Sustainable Development Solutions Network Guide

\begin{tabular}{|c|c|c|}
\hline Learning outcomes & Learning domain & Examples of specific learning objectives \\
\hline $\begin{array}{l}\text { Describe how the } \\
\text { environment and human } \\
\text { health interact at different } \\
\text { levels. }\end{array}$ & Knowledge & $\begin{array}{l}\text { - Discuss how local and global ecological crises impacts on individual patients and communities. } \\
\text { - Describe the interaction between local and global ecological crises and the social determinants of health. } \\
\text { Discuss how the promotion of environmental sustainability generally and in healthcare can support } \\
\text { progress on social determinants of health, health equity and respect for cultural diversity, including } \\
\text { Indigenous traditional knowledge. }\end{array}$ \\
\hline $\begin{array}{l}\text { Demonstrate the knowledge } \\
\text { and capabilities needed to } \\
\text { improve the environmental } \\
\text { sustainability of health } \\
\text { systems, using systems } \\
\text { thinking (see glossary) }\end{array}$ & $\begin{array}{l}\text { Knowledge, } \\
\text { Application }\end{array}$ & $\begin{array}{l}\text { - Evaluate the environmental impacts of a patient pathway and identify ways to enhance environmental } \\
\text { sustainability. } \\
\text { - Describe how changes in disease burden due to environmental change may be identified, characterised } \\
\text { and quantified and how such information can inform planning and practice to address health needs. } \\
\text { - Apply key policies and frameworks related to sustainable development including the SDGs to evaluate a } \\
\text { population health challenge. } \\
\text { - Apply critical thinking, problem-solving and systems thinking to sustainable healthcare challenges. } \\
\text { - ommunicate clearly with health professional colleagues when responding to an ecological challenge or } \\
\text { opportunity in healthcare. }\end{array}$ \\
\hline $\begin{array}{l}\text { Discuss how the duty of } \\
\text { health professionals to } \\
\text { protect and promote health is } \\
\text { impacted by the } \\
\text { interdependence of health } \\
\text { and ecosystems and } \\
\text { implications for health } \\
\text { professionals' personal and } \\
\text { professional lives. }\end{array}$ & $\begin{array}{l}\text { Knowledge, } \\
\text { Values, Mindset } \\
\text { and Agency }\end{array}$ & $\begin{array}{l}\text { - Discuss the role of health professionals in mitigation, adaptation, advocacy and activism in terms of } \\
\text { sustainable development, planetary health and environmental stewardship. } \\
\text { - Demonstrate the ability to advocate for planetary health and the SDGs. } \\
\text { - Demonstrate how to motivate behaviour change to promote environmental sustainability at an } \\
\text { individual, professional and community level. } \\
\text { - Discuss examples of eco-ethical leadership. } \\
\text { - Identify how Indigenous traditional knowledge and voice can inform healthcare practice and promotion } \\
\text { of planetary health and sustainable development in your local context. } \\
\text { Apply an ethical, compassionate, non-hierarchical and holistic approach to addressing the ecological and } \\
\text { social determinants of health. }\end{array}$ \\
\hline
\end{tabular}


Table 2. Examples of learning activities, opportunities and possible assessment approaches that promote transdisciplinary, action-based learning and the involvement of multiple stakeholders (SDSN 2020)

\begin{tabular}{|c|c|c|c|}
\hline Learning activity & Examples & Opportunities & $\begin{array}{l}\text { Possible formative and } \\
\text { summative assessments } \\
\text { Rubrics for all assessments can } \\
\text { be developed based on } \\
\text { intended learning outcomes } \\
\text { and enhance validity of } \\
\text { assessment. }\end{array}$ \\
\hline \multicolumn{4}{|c|}{ Activities with a clinical focus } \\
\hline $\begin{array}{l}\text { Environmental } \\
\text { history in } \\
\text { communication } \\
\text { skills training }\end{array}$ & $\begin{array}{l}\text { In a role play, take a history from a patient who has } \\
\text { been affected by bushfire smoke or has diarrhea as } \\
\text { a result of limited or no access to clean water. }\end{array}$ & $\begin{array}{l}\text { - Promote attention to ecological and social determinants } \\
\text { of health. } \\
\text { - } \quad \text { Practise sensitive enquiry about risk factors. } \\
\text { - Integrate sustainability with history taking skills. } \\
\text { - Address SDG } 3 \text { (promotion of health and well-being for } \\
\text { all). }\end{array}$ & $\begin{array}{l}\text { Formative - observed role play } \\
\text { Summative - OSCE history } \\
\text { station; MCQs \& SAQs } \\
\text { regarding environmental risk } \\
\text { factors }\end{array}$ \\
\hline $\begin{array}{l}\text { Lifecycle analysis of } \\
\text { common medical } \\
\text { resources }\end{array}$ & $\begin{array}{l}\text { Investigate using peer reviewed literature and/or } \\
\text { grey literature (e.g. product information, health } \\
\text { system data) the social, environmental and financial } \\
\text { costs of equipment and medications commonly } \\
\text { used in healthcare. Discuss the implications of these } \\
\text { costs for healthcare planning and healthcare } \\
\text { practice. }\end{array}$ & $\begin{array}{l}\text { - Create awareness of the ecological footprint of medical } \\
\text { equipment from manufacture to disposal. } \\
\text { Raise discussion about ethical issues related to } \\
\text { consumption, e.g. mining for metals/elements and } \\
\text { dismantling of medical devices often happens in low } \\
\text { and low-middle income countries. } \\
\text { Address SDGs } 12 \text { (sustainable consumption and } \\
\text { production), } 14 \text { (marine health) and } 15 \text { (land and } \\
\text { biodiversity protection). }\end{array}$ & $\begin{array}{l}\text { Formative - observation of } \\
\text { group activity, oral assignment, } \\
\text { discussion in clinical practice } \\
\text { Summative - written or oral } \\
\text { assignment, MCQs or SAQs } \\
\text { about measurement methods } \\
\text { or relative costs. }\end{array}$ \\
\hline
\end{tabular}




\begin{tabular}{|c|c|c|c|}
\hline $\begin{array}{l}\text { Concept mapping } \\
\text { exercise, individual } \\
\text { or group, may be } \\
\text { transdisciplinary }\end{array}$ & $\begin{array}{l}\text { Research the environmental impacts of care } \\
\text { provided within one healthcare specialty. Use } \\
\text { graphical tools to demonstrate where } \\
\text { environmental change may alter disease burden and } \\
\text { healthcare seeking and where healthcare may } \\
\text { impact on ecosystems. Consider how causes and } \\
\text { effects interact and varied drivers of costs such as } \\
\text { greenhouse gas emissions and negative impacts on } \\
\text { patients' employment or social support. }\end{array}$ & $\begin{array}{l}\text { - Promote understanding of ecological and social } \\
\text { determinants of health } \\
\text { - } \\
\text { - } \quad \text { Creative activity engages learners and facilitates active } \\
\text { learning. } \\
\text { - Address SDGs 3, 12,13 (climate action), } 14 \text { and } 15 .\end{array}$ & $\begin{array}{l}\text { Formative - assessment of } \\
\text { process, reflections, or the } \\
\text { concept map produced. } \\
\text { Summative - assessment of the } \\
\text { concept map produced using a } \\
\text { rubric based on key learning } \\
\text { outcomes. }\end{array}$ \\
\hline $\begin{array}{l}\text { Practicing } \\
\text { communicating } \\
\text { with patients about } \\
\text { environmental } \\
\text { sustainability and } \\
\text { health promotion } \\
\text { in communication } \\
\text { skills training }\end{array}$ & $\begin{array}{l}\text { In a role play, discuss with a patient a more } \\
\text { environmentally sustainable intervention that can } \\
\text { provide equivalent (or greater) health benefits than } \\
\text { the alternative, e.g.: } \\
\text { - Options with lower environmental impact, e.g. } \\
\text { dry powder inhalers over metered dose inhalers } \\
\text { (asthma pumps) } \\
\text { Lifestyle changes and the co-benefits, i.e. } \\
\text { reducing environmental footprint and improve } \\
\text { health, e.g. reducing meat intake and } \\
\text { increasing grain and vegetable intake; walking } \\
\text { or cycling rather than driving. }\end{array}$ & 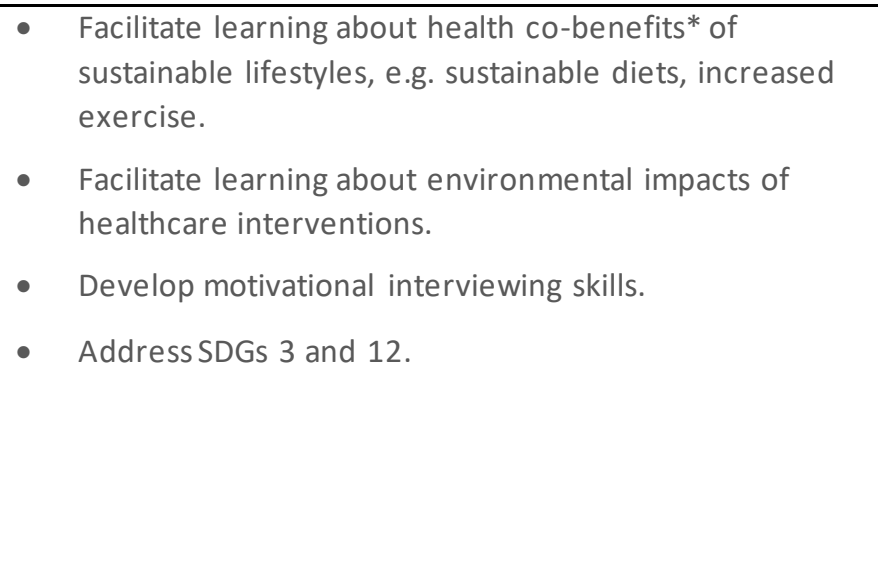 & $\begin{array}{l}\text { Formative - Direct observation } \\
\text { of role play. Summative - OSCE } \\
\text { communication skills station; } \\
\text { MCQs \& SAQs about relevant } \\
\text { evidence, e.g. health co- } \\
\text { benefits, carbon impacts of } \\
\text { healthcare interventions, } \\
\text { and/or related ethical issues. }\end{array}$ \\
\hline $\begin{array}{l}\text { Healthcare } \\
\text { pathway analysis } \\
\text { activity }\end{array}$ & $\begin{array}{l}\text { Explore one patient pathway (e.g. that taken by a } \\
\text { patient presenting to primary care with abdominal } \\
\text { pain and referred to secondary care), and consider } \\
\text { how to apply principles of sustainable healthcare, } \\
\text { including: } \\
\text { - Avoiding investigations that do not add value, } \\
\text { (e.g. imaging not recommended for low back } \\
\text { pain unless neurological damage is suspected) } \\
\text { - Avoiding interventions where a conservative } \\
\text { approach is beneficial or equivalent and lower }\end{array}$ & $\begin{array}{l}\text { - Calculate (or apply calculations of) the financial, social } \\
\text { and environmental costs of healthcare provision } \\
\text { Understand the integration (or lack of integration) of } \\
\text { different healthcare services. } \\
\text { - Consider patient's experiences of accessing healthcare } \\
\text { and take this into account when evaluating a healthcare } \\
\text { pathway. } \\
\text { Identify strategies to achieve both sustainability gains } \\
\text { and improvements in healthcare. } \\
\text { Address SDGs } 12,13,14 \text { and } 15 \text {. }\end{array}$ & $\begin{array}{l}\text { Formative - Observed group } \\
\text { work, group presentation, } \\
\text { individual reflective practice } \\
\text { assignment } \\
\text { Summative - group } \\
\text { presentation, written } \\
\text { assignment (group or } \\
\text { individual) }\end{array}$ \\
\hline
\end{tabular}




\begin{tabular}{|c|c|c|c|}
\hline & $\begin{array}{l}\text { financial or social cost (e.g. watch and wait } \\
\text { approach for hernias can be preferable) } \\
\text { Choosing lower carbon options which are } \\
\text { equivalent in health benefits, e.g. anaesthetic } \\
\text { gases with less global warming potential }\end{array}$ & & \\
\hline $\begin{array}{l}\text { Quality } \\
\text { improvement } \\
\text { projects in primary } \\
\text { or secondary care }\end{array}$ & $\begin{array}{l}\text { Apply the SusQI (Sustainability in Quality } \\
\text { Improvement) framework (Mortimer et al. 2018) to } \\
\text { plan and deliver a project, e.g. about medicines } \\
\text { waste. }\end{array}$ & $\begin{array}{l}\text { - SusQI framework can be applied in different contexts to } \\
\text { focus on local needs and resources. } \\
\text { - Clearly link environmental topics to clinical practice. } \\
\text { - Integrate environmental, social, cultural, financial and } \\
\text { ethical perspectives. } \\
\text { - May address any or all SDGs. }\end{array}$ & $\begin{array}{l}\text { Formative - supervisor's } \\
\text { report, learner's reflective } \\
\text { report. } \\
\text { Summative - report, poster, } \\
\text { oral or other presentation. }\end{array}$ \\
\hline \multicolumn{4}{|c|}{ Activities which may have a clinical, public health or wider sustainability focus } \\
\hline $\begin{array}{l}\text { Literature based } \\
\text { individual or group } \\
\text { research project } \\
\text { and presentation }\end{array}$ & $\begin{array}{l}\text { Research and communicate best evidence on a } \\
\text { planetary health topic. The SDGs offer a useful } \\
\text { framework which could inform the choice of topic } \\
\text { or approach to addressing it. Learners may choose } \\
\text { to produce a video to communicate on their topic or } \\
\text { use another format. }\end{array}$ & $\begin{array}{l}\text { Practise and demonstrate effective communication with } \\
\text { colleagues or the public about planetary health. } \\
\text { - } \quad \text { Learners may choose a topic of personal interest. } \\
\text { digital technology skills. } \\
\text { - May address any or all of the SDGs. }\end{array}$ & $\begin{array}{l}\text { Formative or summative - } \\
\text { Assessment of the presentation } \\
\text { may be carried out using a } \\
\text { rubric based on key learning } \\
\text { outcomes. }\end{array}$ \\
\hline $\begin{array}{l}\text { Written } \\
\text { assignment, } \\
\text { informed by a } \\
\text { literature review }\end{array}$ & $\begin{array}{l}\text { Design an assignment question or select from a list } \\
\text { of questions addressing any planetary health topic. } \\
\text { Construct a written argument in response to the } \\
\text { question. }\end{array}$ & $\begin{array}{l}\text { Develop skills for evidence based practice, including } \\
\text { critical appraisal and synthesizing complex and / or } \\
\text { diverse information. } \\
\text { Demonstrate effective written communication about a } \\
\text { planetary health topic. } \\
\text { - In-depth learning on a chosen planetary health topic. }\end{array}$ & $\begin{array}{l}\text { Formative or summative - A } \\
\text { rubric for marking assignments } \\
\text { may include understanding of } \\
\text { topic, development of } \\
\text { argument and written } \\
\text { communication. This } \\
\text { assessment may, however, be } \\
\text { time-consuming with large } \\
\text { cohorts. }\end{array}$ \\
\hline $\begin{array}{l}\text { Research } \\
\text { assignment }\end{array}$ & $\begin{array}{l}\text { A scenario or challenge that allows learners to } \\
\text { explore the relationship between one or more }\end{array}$ & - Develop qualitative research skills. & $\begin{array}{l}\text { Formative - observation of } \\
\text { team working, learners provide }\end{array}$ \\
\hline
\end{tabular}




\begin{tabular}{|c|c|c|c|}
\hline $\begin{array}{l}\text { involving local or } \\
\text { global } \\
\text { communities, } \\
\text { preferably } \\
\text { transdisciplinary }\end{array}$ & $\begin{array}{l}\text { ecological crises, social determinants of health and } \\
\text { inequality, e.g. exploring how marginalized } \\
\text { Indigenous communities experience these issues, or } \\
\text { investigating gender inequality. } \\
\text { Participatory research (with not about communities) } \\
\text { would be an ideal way to achieve deeper learning if } \\
\text { time and structures to support ethical research are } \\
\text { in place. }\end{array}$ & $\begin{array}{l}\text { Participatory research may promote empathy and } \\
\text { advocacy. } \\
\text { - Learners may focus on an area of personal interest. } \\
\text { - Learners may form lasting connections with students } \\
\text { from other disciplines; they may mutually support each } \\
\text { other to implement positive change. } \\
\text { Mirrors teamwork in clinical practice. } \\
\text { - Learner may explore several SDGs, e.g. } 1 \text { (alleviation of } \\
\text { poverty), } 5 \text { (gender equality) and 13. }\end{array}$ & $\begin{array}{l}\text { feedback on other } \\
\text { presentations, written } \\
\text { reflections on learning. } \\
\text { Summative - research project } \\
\text { write-up as conference } \\
\text { presentation or journal article. }\end{array}$ \\
\hline $\begin{array}{l}\text { Debate, preferably } \\
\text { transdisciplinary }\end{array}$ & $\begin{array}{l}\text { Prepare an argument and debate a motion, which } \\
\text { could be about: } \\
\text { - professional duty - the role of health professionals } \\
\text { in advancing sustainable development through } \\
\text { resource stewardship, } \\
\text { - an ecological justice issue such as the impact of } \\
\text { rising sea levels on Small Island Nations } \\
\text { - responding to a sustainability challenge, e.g. the } \\
\text { link between pandemics and environmental factors. } \\
\text { - an ethical issue, e.g. single-use items in health } \\
\text { care, or the global burden of disease caused by the } \\
\text { health sector emissions. }\end{array}$ & $\begin{array}{l}\text { - } \\
\text { Practice developing an evidence-based viewpoint. } \\
\text { - } \quad \text { Promoging format to encourage engagement. } \\
\text { from different health professions and addressing } \\
\text { resistance or conflict. } \\
\text { - Allows engagement with emotionally challenging, } \\
\text { ethical and/or political issues. } \\
\text { - Learners may form lasting connections with students } \\
\text { from other disciplines; they may mutually support each } \\
\text { - May address various SDGs depending on debate topic. }\end{array}$ & $\begin{array}{l}\text { Formative - observation of } \\
\text { team working in preparation or } \\
\text { during debate. } \\
\text { Summative - observation of } \\
\text { debate presentations and } \\
\text { contributions using assessment } \\
\text { rubric, essay around the debate } \\
\text { question, MCQs or SAQs on the } \\
\text { debate topics. }\end{array}$ \\
\hline $\begin{array}{l}\text { Small group public } \\
\text { health learning } \\
\text { scenario, preferably } \\
\text { interprofessional or } \\
\text { transdisciplinary }\end{array}$ & $\begin{array}{l}\text { Use systems thinking to design a public health } \\
\text { strategy for a scenario (individual patient or } \\
\text { community) addressing an ecological event or crisis } \\
\text { and its impacts on health and/or healthcare } \\
\text { facilities, e.g.: } \\
\text { - } \quad \text { Respiratory disease linked to local air pollution } \\
\text { - } \quad \text { Forced migration due to sea level rise }\end{array}$ & $\begin{array}{l}\text { - Stimulates discussion about health professionals' roles } \\
\text { in, e.g. reducing healthcare's environmental footprint } \\
\text { and advocacy. } \\
\text { - Scenarios can be designed based on local ecological and } \\
\text { public health challenges to promote engagement. } \\
\text { Systems thinking explores interactions between } \\
\text { different parts of a system and potential unintended }\end{array}$ & $\begin{array}{l}\text { Formative - observation of } \\
\text { discussion or presentation by } \\
\text { small group. } \\
\text { Summative - using rubric to } \\
\text { assess small group work or a } \\
\text { group presentation of } \\
\text { discussion and solutions }\end{array}$ \\
\hline
\end{tabular}




\begin{tabular}{|c|c|c|c|}
\hline & $\begin{array}{l}\text { Bush fire causing destruction of a local health } \\
\text { post } \\
\text { - Climate-induced drought and food insecurity } \\
\text { - Ecological crisis causing eco-anxiety, }{ }^{*} \text { grief, } \\
\text { depression and suicide, particularly among } \\
\text { youth }\end{array}$ & $\begin{array}{l}\text { consequences of a given response. Learners can then } \\
\text { apply it to other settings and challenges. } \\
\text { Opportunity to promote transdisciplinary collaboration. }\end{array}$ & $\begin{array}{l}\text { identified, written report of } \\
\text { learning. }\end{array}$ \\
\hline $\begin{array}{l}\text { Reflective } \\
\text { assignment }\end{array}$ & $\begin{array}{l}\text { Explore personal, professional and/or ethical } \\
\text { challenges, e.g. single-use plastic equipment in } \\
\text { terms of sustainable lifestyles and global citizenship } \\
\text { or in relation to healthcare practice. Read relevant } \\
\text { articles, consider how the issues are faced in your } \\
\text { day to day life and may affect current or future } \\
\text { choices. Write an essay or collection of short } \\
\text { reflections on this process. }\end{array}$ & $\begin{array}{l}\text { - Facilitate engagement with personal values, feelings } \\
\text { and attitudes, which may lead to mindset and } \\
\text { behavioural changes. } \\
\text { Identify and explore tensions which may enhance ability } \\
\text { to understand diverse perspectives } \\
\text { - Practice written communication regarding challenging } \\
\text { and sensitive issues } \\
\text { May address any or all SDGs. }\end{array}$ & $\begin{array}{l}\text { Formative - portfolio entries } \\
\text { Summative - portfolio entries } \\
\text { or essay to meet particular } \\
\text { domain requirements, e.g. } \\
\text { professional, advocacy. }\end{array}$ \\
\hline
\end{tabular}

* See appendix 1 (glossary)

Abbreviations: ESH - education for sustainable healthcare; MCQs - multiple choice questions; OSCE - objective structured clinical examination; SAQsshort answer questions, SDGs - Sustainable Development Goals 
Table 3: Proposed road map and recommended targets for education for sustainable healthcare (ESH).

\begin{tabular}{|c|c|c|c|c|}
\hline Focus area & Educator & College / School & $\begin{array}{l}\text { Health professional } \\
\text { accreditation body }\end{array}$ & $\begin{array}{l}\text { National or international health } \\
\text { professional organization }\end{array}$ \\
\hline $\begin{array}{l}\text { Eco-ethical } \\
\text { leadership } \\
\text { includes } \\
\text { environmental } \\
\text { accountability, } \\
\text { modelling good } \\
\text { practice and } \\
\text { supporting eco- } \\
\text { ethical } \\
\text { leadership } \\
\text { development }\end{array}$ & $\begin{array}{l}\text { - Identify whether your } \\
\text { institution has a sustainability } \\
\text { strategy and an ESH plan. } \\
\text { Contact the director of your } \\
\text { institution or another } \\
\text { appropriate colleague to } \\
\text { propose how you could } \\
\text { contribute to existing plan or } \\
\text { develop a plan for ESH. } \\
\text { Contribute to development of a } \\
\text { community of practice for ESH. } \\
\text { Allow space for and/or open } \\
\text { discussions with colleagues and } \\
\text { students to discuss emotional } \\
\text { responses to planetary health } \\
\text { challenges. } \\
\text { Propose that your institution } \\
\text { signs up to the SDGs if it has not } \\
\text { already. }\end{array}$ & $\begin{array}{l}\text { Early 2021: State a commitment to } \\
\text { ESH, e.g. School of Nurses' } \\
\text { commitment to Climate Challenge } \\
\text { (Appendix 2) } \\
\text { 2021: Develop a plan to integrate } \\
\text { planetary health across curricula } \\
\text { and your institution, in line with } \\
\text { SDGs 4, } 12 \text { and 13. } \\
\text { - Involve diverse } \\
\text { experts and } \\
\text { stakeholders, } \\
\text { including } \\
\text { Indigenous } \\
\text { Peoples and other } \\
\text { populations } \\
\text { disproportionately } \\
\text { affected by the } \\
\text { ecological crisis, in } \\
\text { the initiation, } \\
\text { development and } \\
\text { delivery of ESH. } \\
\text { Facilitate the } \\
\text { development of a } \\
\text { community of } \\
\text { practice to } \\
\text { support ESH } \\
\text { development. }\end{array}$ & $\begin{array}{l}\text { 2021: Publish a formal } \\
\text { statement supporting action } \\
\text { on planetary health by health } \\
\text { professionals in training, } \\
\text { health professionals and } \\
\text { health professional } \\
\text { organizations. } \\
\text { 2021: Develop a sustainability } \\
\text { plan for your own } \\
\text { organization, including a } \\
\text { strategy and timeline to reach } \\
\text { net zero emissions. }\end{array}$ & $\begin{array}{l}\text { 2021: Publish a formal statement } \\
\text { calling for urgent integration of } \\
\text { sustainability and/or planetary } \\
\text { health into all health professional } \\
\text { curricula across the spectrum of } \\
\text { training, from undergraduate to } \\
\text { continuing professional } \\
\text { development. } \\
\text { 2021: Measure the } \\
\text { environmental footprint of your } \\
\text { organization and develop and } \\
\text { publish a plan to reach net zero. }\end{array}$ \\
\hline
\end{tabular}




\begin{tabular}{|c|c|c|c|c|c|}
\hline & & $\begin{array}{ll} & \text { Provide space } \\
& \text { (including physical } \\
\text { space \& } \\
\text { curriculum space) } \\
\text { to support the } \\
\text { development of } \\
\text { emotional } \\
\text { resilience. } \\
\text { Work with local } \\
\text { partners to } \\
\text { promote } \\
\text { environmental } \\
\text { accountability } \\
\text { (Box 1), progress } \\
\text { towards the SDGs } \\
\text { and planetary } \\
\text { health. } \\
\text { Use } \\
\text { virtual/distance/remote } \\
\text { learning to reduce travel } \\
\text { where appropriate. }\end{array}$ & & & \\
\hline $\begin{array}{l}\text { Contribute to } \\
\text { faculty } \\
\text { development }\end{array}$ & $\begin{array}{l}\text { Read key references to advance } \\
\text { own knowledge (Appendix 2) } \\
\text { Initiate conversations about } \\
\text { ESH with colleagues who you } \\
\text { have not discussed } \\
\text { sustainability with before - one } \\
\text { within your field and one within } \\
\text { another profession / } \\
\text { department. }\end{array}$ & $\begin{array}{l}\text { 2021: Provide initial faculty } \\
\text { education. } \\
\text { 2022: Provide guidance, training } \\
\text { and resources so that all faculty } \\
\text { members understand how } \\
\text { sustainability relates to the overall } \\
\text { course, including assessment. } \\
\text { 2024: Link ESH to progress markers, } \\
\text { awards, continuing professional } \\
\text { development and career } \\
\text { recognition by }\end{array}$ & $\begin{array}{l}\text { 2021: Recognize sustainability } \\
\text { as a core competency (e.g. } \\
\text { GMC Outcomes for Graduates } \\
\underline{2018} \text { ). } \\
\text { 2022: Recommend ESH be } \\
\text { addressed within supervision, } \\
\text { appraisal and revalidation of } \\
\text { health professionals in training } \\
\text { and health professionals and } \\
\text { provide guidance on how to } \\
\text { achieve this. }\end{array}$ & & $\begin{array}{l}\text { Offer incentives } \\
\text { to drive } \\
\text { innovation, } \\
\text { such as a } \\
\text { planetary } \\
\text { health essay } \\
\text { prize for } \\
\text { students and } \\
\text { prizes for } \\
\text { faculty who } \\
\text { champion ESH. } \\
\text { Provide } \\
\text { resources to }\end{array}$ \\
\hline
\end{tabular}




\begin{tabular}{|c|c|c|c|c|c|}
\hline & & & $\begin{array}{l}\text { Supporting faculty to } \\
\text { develop sustainability } \\
\text { literacy } \\
\text { Engaging health } \\
\text { professionals who } \\
\text { develop and } \\
\text { deliver } \\
\text { sustainable } \\
\text { healthcare in } \\
\text { practice }\end{array}$ & & $\begin{array}{l}\text { educate } \\
\text { educators } \\
\text { about planetary } \\
\text { health. } \\
\text { Provide a } \\
\text { platform for } \\
\text { educators to } \\
\text { share and } \\
\text { access ESH } \\
\text { resources. }\end{array}$ \\
\hline $\begin{array}{l}\text { Identify where } \\
\text { sustainability } \\
\text { and planetary } \\
\text { health can be } \\
\text { incorporated } \\
\text { into your } \\
\text { curriculum }\end{array}$ & & $\begin{array}{l}\text { Identify one other country or } \\
\text { regional contact who is already } \\
\text { engaged in ESH and contact } \\
\text { them to share resources. } \\
\text { Plan to incorporate a planetary } \\
\text { health perspective within a } \\
\text { session or module which you } \\
\text { deliver. }\end{array}$ & $\begin{array}{l}\text { 2021: Seek student input to ESH } \\
\text { development. 2021: Briefly map } \\
\text { sustainability / planetary health } \\
\text { across the curriculum, including } \\
\text { across assessment, and identify } \\
\text { opportunities for integration. } \\
\text { 2022: Develop a plan and strategy } \\
\text { for integrating ESH by } 2025 \text {. }\end{array}$ & $\begin{array}{l}2024 \text { or earlier: Integrate } \\
\text { sustainability at the next } \\
\text { publication of professional } \\
\text { standards in multiple domains } \\
\text { to include knowledge, skills } \\
\text { and values. }\end{array}$ & $\begin{array}{l}\text { Host Special Interest } \\
\text { Groups and events } \\
\text { where educators can } \\
\text { collaborate to develop } \\
\text { new ESH resources } \\
\text { Monitor progress locally, } \\
\text { regionally and } \\
\text { internationally and } \\
\text { disseminate examples of } \\
\text { best practice. }\end{array}$ \\
\hline $\begin{array}{l}\text { Trial new } \\
\text { activities and } \\
\text { assessment to } \\
\text { drive learning }\end{array}$ & & $\begin{aligned} & \text { Design and } \\
& \text { trial one new } \\
& \text { sustainability } \\
& \text { learning } \text { opportunity, } \\
& \text { whether core } \\
& \text { or optional. } \\
& \text { Design and implement an } \\
& \text { appropriate formative or } \\
& \text { summative assessment }\end{aligned}$ & $\begin{array}{l}\text { 2021: Incorporate ESH in at least } \\
\text { one core curriculum element, e.g. } \\
\text { ethics. Seek feedback from staff and } \\
\text { students and disseminate progress } \\
\text { and evaluation findings to faculty. } \\
\text { 2022: Build on previous experience } \\
\text { and address planetary health topics } \\
\text { in a different module / year of the } \\
\text { curriculum. }\end{array}$ & $\begin{array}{l}\text { 2021: Call for ESH to be } \\
\text { included in assessment for } \\
\text { health professional training } \\
\text { courses. } \\
2024 \text { or earlier: Address ESH } \\
\text { within professional exams and } \\
\text { other progression steps for } \\
\text { health professionals. }\end{array}$ & $\begin{array}{l}\text { Host Special Interest } \\
\text { Groups and events } \\
\text { where educators can } \\
\text { network and discuss and } \\
\text { develop assessment for } \\
\text { ESH. }\end{array}$ \\
\hline $\begin{array}{l}\text { Integrate } \\
\text { sustainability }\end{array}$ & & $\begin{array}{l}\text { Work with } \\
\text { your } \\
\end{array}$ & $\begin{array}{l}\text { 2023: Incorporation of sustainability } \\
\text { and planetary health across at least }\end{array}$ & $\begin{array}{l}2024 \text { or earlier: Develop } \\
\text { indicators for use at national }\end{array}$ & $\begin{array}{ll}\text { Provide a platform for } \\
\text { educators and students }\end{array}$ \\
\hline
\end{tabular}




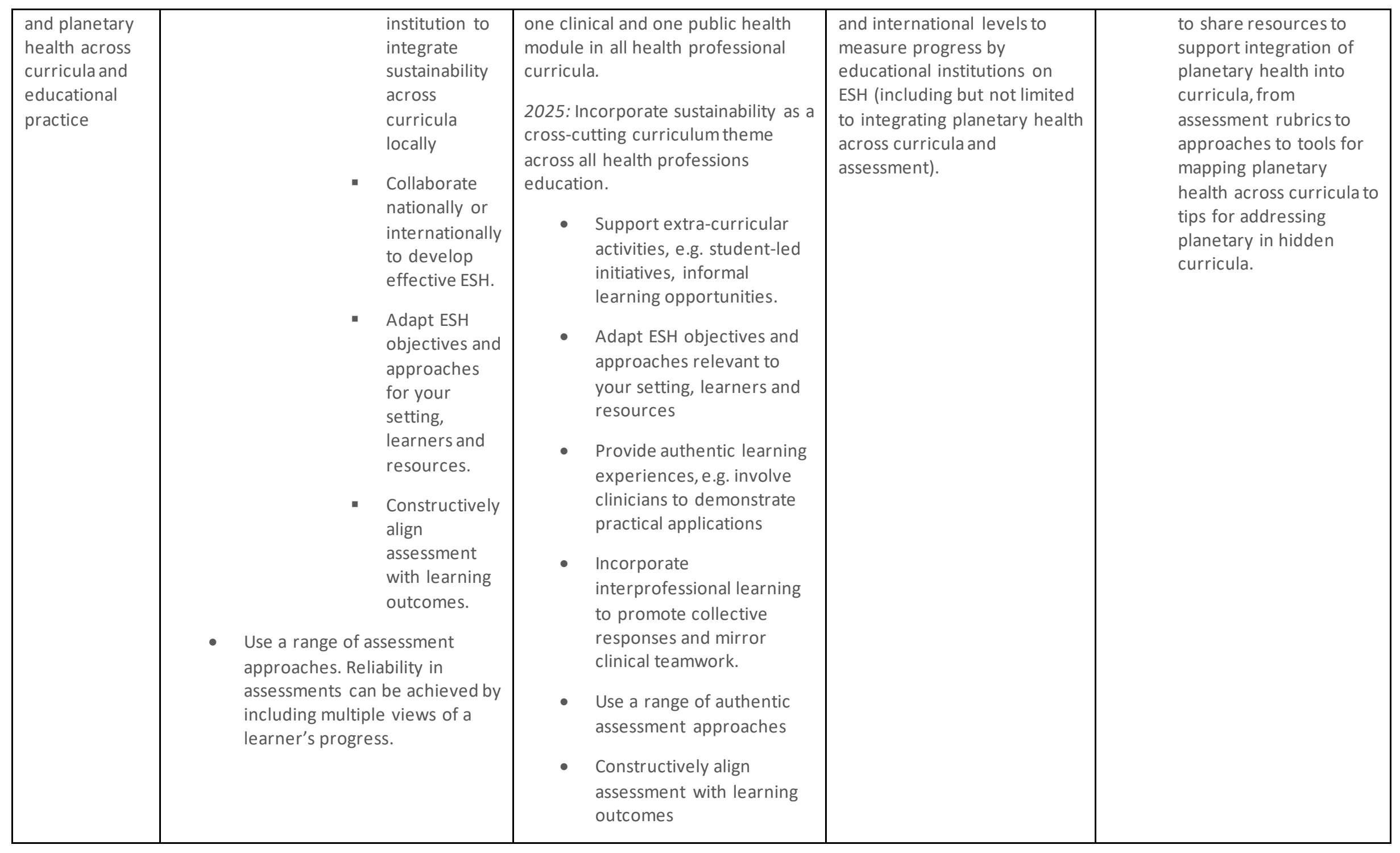




\begin{tabular}{|c|c|c|c|c|c|c|}
\hline $\begin{array}{l}\text { Ongoing } \\
\text { collaboration, } \\
\text { development } \\
\text { and evaluation }\end{array}$ & & $\begin{array}{l}\text { Learn from bes } \\
\text { other institutio } \\
\text { from collabora } \\
\text { sharing across } \\
\text { disciplines and } \\
\text { including via or } \\
\text { e.g. Centre for } \\
\text { Healthcare, Glc } \\
\text { on Climate and } \\
\text { Education, } \frac{\text { Plat }}{\text { Alliance \& Nurs }}\end{array}$ & $\begin{array}{l}\text { Work and } \\
\text { learn } \\
\text { collaboratively } \\
\text { with } \\
\text { colleagues } \\
\text { from different } \\
\text { disciplines. } \\
\text { oractice in } \\
\text { and benefit } \\
\text { n and resource } \\
\text { stitutions, } \\
\text { orders, } \\
\text { ne platforms, } \\
\text { stainable } \\
\text { al Consortium } \\
\text { ealth } \\
\text { tary Health } \\
\text { S. }\end{array}$ & $\begin{array}{l}\text { Review these actions on an annual } \\
\text { basis: } \\
\text { Evaluate progress towards } \\
\text { integration of planetary } \\
\text { health across entire } \\
\text { curriculum. } \\
\text { Canvas views of health } \\
\text { professions educators and } \\
\text { students on institutional } \\
\text { progress on ESH. } \\
\text { Encourage faculty to join } \\
\text { networks of educators and } \\
\text { contribute to movement- } \\
\text { building and advocacy for } \\
\text { policy action within and } \\
\text { external to the educational } \\
\text { sphere. }\end{array}$ & $\begin{array}{l}\text { Collaborate with health } \\
\text { professional accreditation } \\
\text { bodies internationally to } \\
\text { support ESH. }\end{array}$ & $\begin{array}{l}\text { 2021: Provide a platform for } \\
\text { educators from different } \\
\text { institutions to discuss ESH } \\
\text { progress, challenges, approaches } \\
\text { and leadership. }\end{array}$ \\
\hline
\end{tabular}




\section{Supplementary materials}

\section{Appendix 1. Glossary of terms relating to Planetary Health and Education for Sustainable Healthcare}

\section{Anthropocene}

A new planetary epoch in which human impacts are the dominant force shaping the Earth's physical, chemical and biological systems (Lewis and Maslin 2015).

\section{Co-benefits}

The health benefits that result from measures to mitigate environmental degradation. Mitigation measures to limit climate change, for example, by halving greenhouse gas emissions by 2050 in relation to 2005 would reduce premature deaths caused by air pollution by $20-40 \%$, depending on the countries (United Nations Economic Commission for Europe 2016). In the context of a clinical consultation, patients can contribute to reducing their environ mental footprint by adopting a healthy lifestyle, e.g. walking or cycling to work and reducing their red meat intake.

\section{Consensus}

A generally accepted opinion among a group of people (Cambridge English Dictionary, 2020). A consensus process is "a creative and dynamic way of reaching agreement between all members of a group." Rather than voting or taking a majority opinion, a consensus progress involves taking all ideas and opinions into account and finding solutions or opinions that all group members can actively support or at least accept (Seeds for Change 2020). In developing this Statement, rather than voting or majority decision making, all ideas, opinions and concerns were debated untila solution was found that everyone in the group could accept.

\section{Continuing professional development}

Learning activities in which professionals engage to develop and enhance their abilities related to professional activities, following completion of formal training. In some instances, this might be mandatory, depending on the accreditation body.

\section{Determinants of health (ecological and social)}

The multitude of factors that influence the health of individuals and populations. Although the World Health Organization refers to public health, environmental and social determinants of health (WHO 2020), Parkes and colleagues (2020) use 'ecological determinants of health' and 'social determinants of health' and discuss an eco-social approach to public health. This is consistent with long-standing and ongoing calls from Indigenous communities and terminology from knowledge systems (Greenwood et al. 2015; Ratima et al. 2019), closer attention to relationships and interconnections helps to overcome false dichotomies between the ecological and social influences on health, and provides the foundation for what is described here as an eco-social approach".

Parkes and colleagues (2020) use 'ecological' rather than 'environmental' as the term ecological encompasses the dynamic relationships within ecosystems that create the foundations for all life, 
such as water, air, food and "the constituent parts for all life-giving systems necessary for the health of humans and other species" (p. 61).

\section{Doughnut economics}

Raworth (2017) conceptualised the Doughnut, a conceptual framework of social and planetary boundaries (definition below and see Figure 1). The Doughnut combines two concentric radar charts to depict social boundaries (twelve dimensions and their indicators) and ecological boundaries (nine dimensions and their indicators) within which we need to operate for human health and well-being.

The inner boundary is a social foundation, below which lie shortfalls in well-being, such as hunger, ill health, illiteracy, and energy poverty. The outer boundary is an ecological ceiling beyond which lies an overshoot of pressure on Earth's life-supporting systems, in areas such as chemical pollution, ocean acidification and ozone depletion. Four planetary boundaries have already been overshot: climate change, biodiversity loss, land conversion and nitrogen and phosphorous loading. Chemical and air pollution are the next two boundaries that we risk overshooting.

\section{Eco-anxiety}

The experience of anxiety, in relation to the existential threat posed by the ecological crisis. It may manifest as severe worry about environmental issues and may cause loss of appetite, sleeplessness and panic attacks (Ingle and Mikulewicz 2020).

\section{Eco-ethical leadership}

Inspirational and adaptive leadership involving values, collaboration, justice, advocacy and, if need be, activism to ensure ecological sustainability and planetary health principles (McKimm and McLean 2020).

\section{Ecological crisis}

Multiple unprecedented global environmental changes (GECs) have occurred since the middle of the last century, including biodiversity loss, climate change, ocean acidification, freshwater depletion, soil degradation and changes in nutrient cycling. These human-induced impacts threaten the natural systems that support life on earth (Frumkin and Haines 2019). Collectively, these GECs reflect our current global ecological crisis. Environmental changes and ecological crises are also occurring at local and regional levels.

\section{Education for sustainable healthcare (ESH)}

The process of equipping current and future health professionals with the knowledge, attitudes, confidence and capacity to provide environmentally sustainable services through health professional education (Walpole and Mortimer 2017).

The UK's Centre for Sustainable Healthcare used a consultation process to develop three Priority Learning Outcomes (Thompson et al. 2014), which encompass ESH: 
1. Describe how the environment and human health interact at different levels.

2. Demonstrate the knowledge and skills needed to improve the environmental sustainability of health systems.

3. Discuss how the duty of a doctor to protect and promote health is shape d by the dependence of human health on the local and global environment.

\section{Environmental accountability}

An environmentally accountable institution is both environmentally responsible and responsive: aware of global health challenges faced by society and recognises the environmental impact of its activities (Pearson et al. 2015). The institution should also have policies in place to measure and reduce its environmental impact, and work through education and research to promote sustainable healthcare (Boelen et al. 2016).

\section{Environmental stewardship}

Environmental stewardship refers to overseeing and managing environments and human impacts on environments. In healthcare, this implies overseeing and managing the environm ental impacts of health systems (Bennett et al. 2018)

\section{Health professional}

An individual who has gained a professional qualification for work in the health system, whether in health care delivery, public health or a management or supporting role.

\section{Health professional in training}

A 'student' or individual studying or training to become a health professional.

\section{Indigenous Peoples}

Indigenous Peoples are distinct social and cultural groups which share collective ancestral ties to the lands and natural resources where they live, occupy or from which they have been displaced. Their identities, cultures, livelihoods, as well as their physical and spiritual well-being, are inextricably linked to the land and natural resources on which they depend. Many Indigenous Peoples still maintain languages distinct from the official language or languages of the country or region in which they reside.

(https://www.worldbank.org/en/topic/indigenouspeoples)

\section{Indigenous traditional knowledge}


Systems of knowledge, know-how, skills and practices that are developed, sustained and passed on from generation to generation within a community, often forming part of Indigenous Peoples' cultural or spiritual identity (Redvers et al. 2020). Developed from experience gained over the centuries and adapted to the local culture and environment, traditional knowledge is often transmitted orally from generation to generation. It tends to be collectively owned and can be expressed in stories, songs, folklore, proverbs, cultural values, beliefs, rituals etc. It is also the source for the traditional use and management of lands, territories and resources, with Indigenous agricultural practices that care for the earth, without depleting the resources. Indigenous peoples follow oral traditions, with dances, paintings, carvings and other artistical expressions, that are practiced and passed down through millennia.

(https://www.un.org/development/desa/indigenouspeoples/wpcontent/uploads/sites/19/2019/04/Traditional-Knowledge-backgrounder-FINAL.pdf)

\section{Planetary boundaries}

There have been several references to planetary boundaries but Rockström and colleagues' (2009) article is probably the most widely cited. Planetary boundary is used to "define the safe operating space for humanity with respect to the Earth system and are associated with the planet's biophysical systems or processes." (p. 472). In 2009, they identified biodiversity loss and the nitrogen cycle as having exceeded planetary boundaries.

\section{Planetary health}

Two of the commonly used definitions of planetary health are the more recent Lancet definition of Whitmee et al. (2015), which originated from the work of Horton and colleagues (2014), appealing for public health to be reconceptualized as planetary health and the more holistic perspective reflected in the Canmore Declaration Principles.

- Definition appearing in the Lancet: "The achievement of the highest attainable standard of health, wellbeing and equity worldwide through judicious attention to the human systems political, economic, and social - that shape the future of humanity and the Earth's natural systems that define the safe environmental limits within which humanity can flouris $h$. Put simply, planetary health is the health of human civilization and the state of the natural systems on which it depends (Whitmee et al. 2015; p. 1978)

- Excerpt from the Canmore Declaration: "Planetary health, inseparably bonded to human health, is defined as the interdependent vitality of all natural and anthropogenic ecosystems; this vitality includes the more broadly defined human-constructed social, political and economic ecosystems that favor health equity and the opportunity to strive for high level wellness; this definition also includes the business ecosystems that influence sustainable and health-promoting local and global commerce.... Planetary health is rooted in ancestral concepts of the unity of life; the complexity of the challenges we face demands integrationist approaches; responsibility for planetary health requires us to relinquish conventional professional, societal and cultural partitions and to develop contextual coalitions based both on science and broader cultural narratives." (Prescott et al. 2018; p.3) 
The more recent definition that appears in the Lancet has been criticized for being anthropocentric and not acknowledging any historic planetary health definitions and trad itional knowledge systems that embrace the interdependence of human health and well-being and the natural environment (Prescott and Logan 2019).

\section{Sustainable development}

The term 'sustainable development' is attributed to the Brundtland Commission which, in its 1987 Report, OurCommon Future, and is defined as the "ability to make development sustainable - to ensure that it meets the needs of the present without compromising the ability offuture generations to meet their own needs" (World Commission on Environment and Development 1987). The underpinning philosophy of Brundtland's conception of sustainable development stems from an understanding that critical global environmental problems resulted primarily from The Brundtland Commission's work was instigated following concerns raised about the conflicts between environment and development at the 1972 Stockholm Conference on the Human Environment.

\section{Sustainable healthcare}

Sustainable healthcare focuses on the improvement of health and better delivery of healthcare rather than late intervention in disease, with resulting benefits to patients and to the ecosystems on which human health depends, thus serving to provide high-quality healthcare now without compromising the ability to meet the health needs of the future (Tun 2019).

\section{Sustainability}

Emerging from the Brundtland Report, sustainability has come to be viewed as "something to do with social equity and economic development, in addition to environmental protection" (Lombardi et al. 2011; p. 276). In the context of healthcare, sustainability (and hence sustainable development) is viewed as the intersection of the three dimensions of sustainability: Economy, society and the environment and which has come to be known in business as triple bottom line (TBL). Elkington (1994), who first proposed the TBL model, advocates going beyond the TBL to a stronger model of sustainability (https://hbr.org/2018/06/25-years-ago-i-coined-the-phrase-triple-bottom-line-hereswhy-im-giving-up-on-it).

An alternative strong sustainability model is that of Lombardi et al. (2011) which reflects a nested dependency, with the economy being a social construct within society and with society dependent on the natural environment and ecosystems for survival (Figure below). Without healthy ecosystems and natural environment, it will be difficult to meet the social determinants of health. 
Weak sustainability model

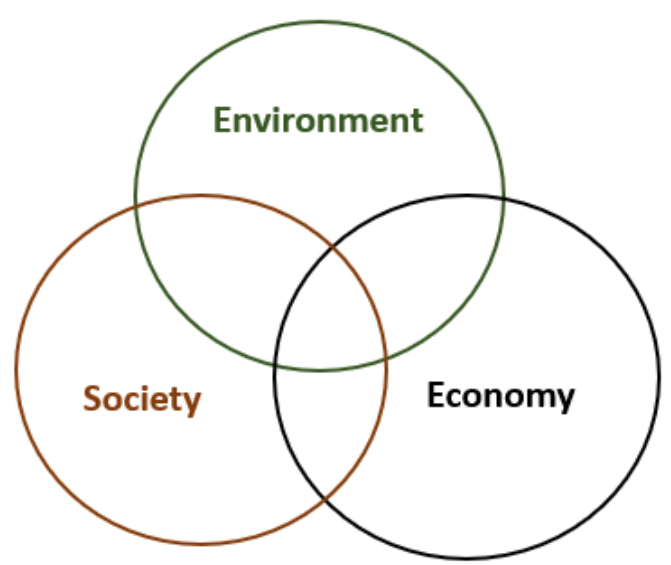

\section{Strong sustainability model}

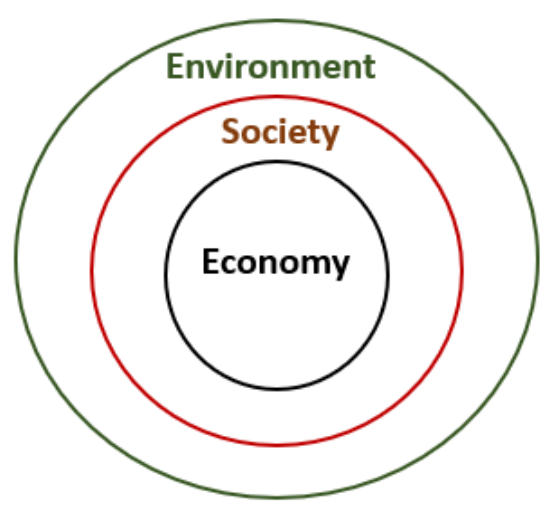

Figure: Weak and strong sustainability models (redrawn from Lombardiet al., 2011)

\section{Sustainability literacy}

The knowledge, skills and mindsets that allow individuals to become deeply committed to building a sustainable future and assisting in making informed and effective decisions to this end (UN 2018).

\section{Systems thinking}

An approach which acknowledges the interdependence of all agents in systems, and is particularly useful in addressing complex or wicked problems. It examines the linkages and interactions between all components of a system. Small changes in one part of a system can have large, unintended consequences throughout the system (Learning for Sustainability 2020). The healthcare system and education system are examples of two interconnected systems. In education for sustainable healthcare, there needs to be communication and integration between the two systems to bridge the theory and practice.

\section{References}

Bennett NJ, Whitty TS, Finkbeiner E. et al. 2018. Environmental stewardship: A conceptual review and analytical framework. Environ Manag. 61: 597-614.

Boelen C, Pearson D, Kaufman A, Rourke J, Woollard R, Marsh DC, Gibbs. T. 2016. Producing a socially accountable medical school: AMEE Guide No. 109. Med Teach. 38(11):1078-1091.

Cambridge English Dictionary. 2020. https://dictionary.cambridge.org/dictionary/english/consensus.

Frumkin H, Haines A. 2019. Global environmental change and noncommunicable disease risks. Ann Rev Pub Health. 40 :261-282. https://www.annualreviews.org/doi/abs/10.1146/annurev-publhealth040218-043706

Greenwood M, de Leeuw S, Lindsay N M, Reading C. (Eds.). 2015. Determinants of Indigenous Peoples' Health in Canada: Beyond the Social. Toronto: Canadian Scholars Press. 
Horton R, Beaglehole R, Bonita R, Raeburn J, McKee M, Wall S. 2014. From public to planetary health: a manifesto. Lancet. 383(9920):847.

https://www.thelancet.com/journals/lancet/article/PIIS0140-6736(14)60409-8/fulltext

Ingle HE, Mikulewicz M. 2020. Mental health and climate change: tackling invisible injustice. Lancet Planet Health. 4:e128-e130. https://www.thelancet.com/action/showPdf? pii=S2542-

5196\%2820\%2930081-4

Learning for sustainability. Systems Thinking: https://learningforsustainability.net/systems-thinking/

Lewis SL, Maslin MA. 2015. Defining the Anthropocene. Nature. 519(7542):171-180.

Lombardi RD, Porter L, Barber A, et al. 2011. C conceptualising sustainability in UK urban

regeneration: a discursive formation. Urban Stud. 48(2):273-296.

https://journals.sagepub.com/doi/10.1177/0042098009360690

McKimm J, McLean M. 2020. Rethinking health professions' education leadership: Developing 'ecoethical' leaders for a more sustainable world and future. Med Teach. 42(8):1-6.

Parkes MW, Poland B, Allison S., et al. 2020. Preparing for the future of public health: The ecological determinants of health and the call for an eco-social approach to public health education. Can J Pub Health. 111(1):60-64. https://doi.org/10.17269/s41997-019-00263-8

Pearson D, Walpole S, Barna S. 2015. Challenges to professionalism: Social accountability and global environmental change. Medical Teacher. 2015;37(9):825-830.

Prescott S, Logan A, Albrecht G, et al. 2018. The Canmore Declaration: Statement of Principles for Planetary Health. Challenges 9(2):31. https://www.mdpi.com/2078-1547/9/2/31

Prescott S, Logan A. 2019. Planetary Health: From the wellspring of holistic medicine to personal and public health imperative. Explore.15(2):98-106.

Ratima M, Marti, D, Castleden H, Delormier T. 2019. Indigenous voices and knowledge systems promoting planetary health, health equity, and sustainable development now and for future generations. Global Health Prom. 26(Suppl3): 3-5.

Raworth K. 2017. A Doughnut for the Anthropocene: humanity's co mpass in the 21st century. Lancet Planet Health. 1:e48-e49. https://www.thelancet.com/action/showPdf?pii=S2542-

5196\%2817\%2930028-1.

Rockström J, Steffen W, Noone K. et al. 2009. A safe operating space for

humanity. Nature. 461: 472-475. https://doi.org/10.1038/461472a.

Redvers N, Schultz C, Prince MV, Cunningham M, Jones R, Blondin B. 2020. Indigenous perspectives on education for sustainable healthcare. Med Teach. 42(10):1085-1090.

Seeds for Change, 2020. Consensus decision making. $2^{\text {nd }}$ edition, published online.

https://www.seedsforchange.org.uk/consensus.

Steffen W, Richardson K, Rockström J et al. 2015. Planetary boundaries: Guiding human development on a changing planet. Science. 347(6223):736.

https://science.sciencemag.org/content/347/6223/1259855

Thompson T, Walpole S, Braithwaite I, Inman A, Barna S, Mortimer F. 2014. Learning objectives for sustainable health care. Lancet. 384:1924-1925. 
Tun S. 2019. Fulfilling a new obligation: Teaching and learning of sustainable healthcare in the medical education curriculum, Med Teach. 41(10):1168-1177.

United Nations. 2018. Raising awareness and assessing sustainability literacy on SDG 7. https://sustainabledevelopment.un.org/sdinaction/hesi/literacy\#: :text=\%22Sustainability\%20Litera cy\%22\%20is\%20the\%20knowledge, effective\%20decisions\%20to\%20this\%20end.

United Nations Economic Commission for Europe. 2016. Sustainable Development Brief No. 2. The co-benefits of climate change mitigation.

http://www.unece.org/fileadmin/DAM/Sustainable_Development_No. 2 _Final_Draft_OK_2.pdf.

Walpole SC, Mortimer F. 2017. Evaluation of a collaborative project to develop sustainable healthcare education in eight UK medical schools. Pub Health.150:134-148.

https://www.sciencedirect.com/science/article/pii/S0033350617301944

Whitmee S, Haines A, Beyrer C, Boltz F, Capon A, de Souza Dias B, Ezeh A, Frumkin H, Gong P, Head P. 2015. Safeguarding human health in the Anthropocene epoch: report of the Rockefeller Foundation-Lancet Commission on planetary health. Lancet. 386(10007):1973-2028. https://www.thelancet.com/journals/lancet/article/PIIS0140-6736(15)60901-1/fulltext.

World Commission on Environment and Development. 1987. Our Common Future. Oxford: Oxford University Press. p. 27. https://archive.org/details/ourcommonfuture00worl

World Health Organization. 2020. WHO Global Strategy on Health, Environment and Climate Change: The transformation needed to improve lives and well-being sustainably through healthy environments. Geneva: World Health Organization. Licence: CCBY-NCSA3.0IGO. https://apps.who.int/iris/rest/bitstreams/1276971/retrieve 


\section{Appendix 2: Resources to guide sustainability and planetary health implementation}

The supplementary material in this document contains examples of projects across the world that are advancing education for sustainable healthcare. This serves as an introduction to those wishing to read more about practical ideas for implementing education for sustainable healthcare in their own contexts. It has been compiled through recommendations from the AMEE Consensus Statement contributors. The Consensus Statement reference list is also an excellent resource. We hope it serves as a useful starting point.

\section{Competency frameworks}

Example from undergraduate education

Global Consortium on Climate and Health Education

https://www.publichealth.columbia.edu/sites/default/files/pdf/gcche_competencies.pdf

\section{Example from Nursing}

NurSUS

http://nursus.eu/

\section{Example from Medicine}

Walpole SC, Vyas A, Maxwell J, et al. 2017. Building an environmentally accountable medical curriculum through international collaboration. Med Teach. 39:1040-1050.

doi:10.1080/0142159X.2017.1342031.

\section{Example from Physiotherapy}

Environmental Physiotherapy Agenda 2023

https://eptagenda2023.com/agenda

Resources and projects

\section{Canadian Community of Practice in Ecosystem Approaches to Health (CoPEH)}

\section{http://www.copeh-canada.org/en/about-us.html}

CoPEH-Canada is a community of scholars and practitioners dedicated to the understanding, teaching and application of ecosystem approaches to address current challenges to health and sustainability.

Centre for Sustainable Healthcare: Education for Sustainable Healthcare network 
A peer network to support sustainable healthcare and planetary health education: (1) understand the links between human health and the environment; (2) develop skills to bring about a sustainable health service; (3) discuss the duty of a health professional to protect the health of the public in a time of global environmental change.

\section{EcoHealth International}

https://www.ecohealthinternational.org/about-us/

Ecohealth International's mission is to strive for sustainable health of people, wild life and ecosystems by promoting discovery, understanding and transdisciplinary teaching, research and problem-solving that harnesses expertise in a range of fields of scholarship (including natural, social and health sciences and the humanities).

\section{EDGE: Ecological Determinants Group on Education}

https://www.cpha.ca/EDGE

The Ecological Determinants Group on Education (EDGE) aims to bring together public health and allied professionals, researchers and educators with interest and expertise in the ecological determinants of health (EDH) to promote the integration of EDH with public health education, training, and professional development, attending to issues of content as well as issues of pedagogy (and the alignment between these).

\section{Global Consortium on Climate and Health Education (GCCHE)}

\section{https://www.publichealth.columbia.edu/sites/default/files/pdf/gcche_competencies.pdf}

The GCCHE's vision is that all health professionals throughout the world - doctors, nurses, and public health leaders and practitioners - will be trained to prevent, reduce, and respond to the health impacts of climate change. To advance progress towards this vision, the GCCHE has convened an Advisory Council and Coordinating Committee of global experts, is preparing resources for all schools of medicine, nursing, and public health to use and is obtaining commitments from health professions schools in all regions of the world to include education on the health impacts of climate change in their education.

\section{Greener Anaesthesia and Sustainability Project (GASP)}

www.gaspanaesthesia.com

GASP is a multidisciplinary group comprising healthcare workers, sustainability experts and healthcare managers working to reduce the environmental impact of healthcare in the United Kingdom. The nationwide network focuses on 4 main streams: Education for Sustainable Healthcare, Quality Improvement, Lobbying and Consulting. Over the last two years, the group has embarked on a Medical School Roadshow in the UK focusing empowering medical students to take what they have learnt in the classroom into the clinical setting. The network then links interested students into GASP Quality Improvement Projects happening local to them. GASP also delivers local, regional and national teaching on Sustainable Healthcare to healthcare professionals in the United Kingdom. 


\section{HEART}

\section{https://www.cfms.org/what-we-do/global-health/heart.html}

The Health and Environment Adaptive Response Task force (HEART) is a Canadian Federation of Medical Students (CFMS) group established in 2016 to help coordinate advocacy efforts among Canadian medical students regarding current issues in environmental health and climate change. HEART has worked on raising awareness about planetary health through various avenues and developed a set of core curricular competencies that address the main environmental iss ues to be included in the medical school curriculum across Canada.

\section{inVIVO Planetary Health}

https://www.invivoplanet.com/

inVIVO Planetary Health is a diverse group of scientists, clinicians, educators and advocates from many fields, who recognize the importance of approaching complex environmental issues from a holistic and integrated perspective - extending and combining the typical focus on the biological and psychological level, with the wider sociological and environmental determinants of human health - and understanding how these are inter-related to societal health. This initiative provides both the impetus for a series of specific projects and provides an umbrella framework to integrate these in a unique way.

\section{https://www.invivoplanet.com/}

A collaborative network for planetary health with the following mission: To transform personal and planetary health through awareness, attitudes and actions, and a deeper understanding of how all systems are interconnected and interdependent.

The 10 inVIVO Principles for Planetary Health are:

1. Sustainable vitality for all systems

2. Values and Purpose

3. Integration and Unity

4. Narrative Health

5. Planetary Consciousness

6. Nature Relatedness

7. Biopsychosocial interdependence

8. Advocacy

9. Countering elitism, social dominance and marginalization 
10. Personal commitment to shaping new normative behaviors

\section{Medical Teacher special issue on Educating for Sustainable Healthcare}

\section{https://www.tandfonline.com/toc/imte20/current}

Medical Teacher is the official journal of the Association for Medical Education in Europe (AMEE), publishing research on medical education teaching approaches and methods. Volume 41, 2019

- Issue 10 is dedicated to teaching sustainable healthcare, planetary health and Indigenous perspectives in the health professions. The article abstracts are open source until the end of 2020. The accompanying infographic (second link) can be used to explore the special issue and the themes.

Infographic: https://think.taylorandfrancis.com/imte-special-issue-infographic/

\section{Nurses' Climate Challenge}

\section{https://nursesclimatechallenge.org/about}

This group aims to mobilise nurses across the country to educate a total of 50,000 of their colleagues about the impacts of climate change on human health and build a national network of informed and more engaged health professionals in care settings. Nurse Climate Champions receive access to a free, comprehensive set of easy-to-use resources to use at educational events (e.g. at a staff meeting) and then report the number of health professionals they have educated.

\section{NurSUS}

http://nursus.eu/

This is a strategic partnership of four universities which aims to enhance the availability of an evidence-based learning offer in Sustainability Literacy and Competency (SLC) in nurse education. They do this by developing innovative teaching and learning approaches/materials, disseminating good practice and promoting take-up of the learning materials through strategic use of information technologies.

\section{Planetary Health Alliance (PHA)}

\section{https://www.planetaryhealthalliance.org/planetary-health}

The Planetary Health Alliance is a consortium of over 200 universities, non-governmental organizations, research institutes and government entities from around the world committed to understanding and addressing global environmental change and its health impacts. To support the rapid growth of a robust, interdisciplinary field of planetary health, the PHA is focused on: building a global planetary health community that crosses sectors, disciplines, generations, and geographies; facilitating the training of the next generation of planetary health leaders through the development of mentorship opportunities and foundational open-access educational resources from primary to university levels; and mainstreaming planetary health science through broad public outreach and direct engagement with policymakers.

The PHA has facilitated the creation of a set of cross-cutting principles for planetary health education (Stone et al. 2018) that intersect education at all levels and in all regions of the world. The vision is that they are a set of key messages every educator teaching planetary health at any level should impart upon their students. The team who developed them hope that educators around the 
world will engage with the content, share their resources and connect with the planetary health community to develop these principles further.

Stone S, Myers S, Golden C. 2018. Cross-cutting principles for planetary health education. Lancet Planet Health. 2:192-193

\section{Planetary Health Report Card}

https://phreportcard.org/

The Planetary Health Report Card is a medical-student driven initiative with the purpose of increasing planetary health awareness and accountability among medical schools. They have created a standardized Planetary Health Report Card that medical students internationally can use to grade and compare their home institutions. It aims to compare medical schools in five key areas: 1) planetary health curriculum, 2) interdisciplinary research in health and environment, 3) university support for student planetary health initiatives, 4) community outreach and advocacy-centered on environmental health impacts, and 5) campus sustainability. This project is inspired by the Racial Justice Report Card, an initiative from White Coats 4 Black Lives that has led to substantial impactful change.

\section{SDG Academy}

\section{https://sdgacademy.org/}

The SDG Academy is the online education platform of the Sustainable Development Solutions Network (SDSN), a global initiative for the United Nations. Comprising a team of experts in international development, policy, pedagogy and content production who create and curate free educational resources on sustainable development and offer them as a global public good. The courses cover the headline issues and a multitude of interdisciplinary topics related to the 17 Sustainable Development Goals, a set of aims and targets adopted by member states of the United Nations in 2015. 
University of Minnesota climate change and health: An interprofessional response

https://globalhealthcenter.umn.edu/climate-change-and-health-curriculum

The 'Climate Champions' team at University of Minnesota has developed PowerPoint presentations that can be used to introduce the connection between climate change and health to health professionals. They also connect students with faculty and community members working in health care sustainability and climate change to develop project ideas.

\section{World Federation for Occupational Therapy}

Sustainability matters: Guiding principles for sustainability in occupational therapy practice, education and scholarship.

http://ergoterapie.cz/wp-content/uploads/2018/11/wfot_sustainability_guiding_principles.pdf 